\title{
冥王代の「生きた微化石」OD1 と超還元場の歴史
}

\author{
佐 藤 友 颜 吉 屋一美 丸 山茂 徳*,** \\ History of the Hadean "Living Microfossil" OD1 and Ultra-reducing Environments
}

Tomohiko SATO*, Kazumi YOSHIYA* and Shigenori MARUYAMA*,**

[Received 7 March, 2018; Accepted 21 November, 2018]

\begin{abstract}
Phylogenetic analysis is one of the useful tools available for revealing the evolution of life on the Earth; however, it has difficulty in principle distinguishing old and new genomes just by comparing phylogenomic trees. To overcome this difficulty, a new method is introduced which utilizes the Earth's history derived from geologic information to trace genomic evolution. This idea is inspired by Darwin's natural selection, and explains how living organisms change with the environment. In other words, life's genome does not change if the environment remains the same. A key is the birthplace of life on Hadean Earth, which is thought to be an ultra-reducing environment with $\mathrm{H}_{2}$ produced in abundance through serpentinization. OD1 is a potential microbe that has survived on the Earth since the Hadean. Its habitat, Hakuba-Happo in Japan, is a unique serpentinite-hosted hydrothermal system on land, and it has avoided evolution by remaining in a super-reducing environment from the Hadean to the present. OD1 is regarded as a "living fossil" of the Hadean microbe. Ultra-reducing environments have disappeared over the Earth's history. How has OD1 survived since the Hadean to the present? A possible scenario is proposed based on Plate Tectonics. OD1 habitats have gone through the following transitions: (1) super-reducing environment in a natural nuclear geyser on a primordial continent in the Hadean; (2) serpentinite-hosted hydrothermal system along a mid-oceanic ridge transform fault during the Archean-Proterozoic; (3) subduction-accretion and escape from oxygenated Phanerozoic ocean floor; and, (4) jacked up by growth of accretionary complexes and taking refuge in a hydrothermal system above a volcanic front. OD1 habitats have been reduced with geological age as free oxygen has increased in the surface environment. OD1 may be a "living microfossil" of the Hadean, making its way continuously through ultra-reducing environments on a tightrope.
\end{abstract}

Key words : Hadean, OD1, serpentinite, hydrothermal system, ultra-reducing キーワード：冥王代, OD1, 蛇紋岩, 熱水系, 超還元

\section{I.はじめに}

「生命の起源」の研究は, 無機物から有機物を 合成し生命を産み出すボトムアップのアプローチ
と，現在生きている生命から原始的な生命へとさ かのぼるトップダウンのアプローチとに大別され る。トップダウンのアプローチにおける重要な課 題の一つは, 現在の地球に生きているもっとも原

\footnotetext{
* 東京工業大学地球生命研究所

**ノボシビルスク国立総合大学

* Earth-Life Science Institute, Tokyo Institute of Technology, Tokyo, 152-8550, Japan

** Novosibirsk State University, Pirogova 1, 630090, Russia
} 

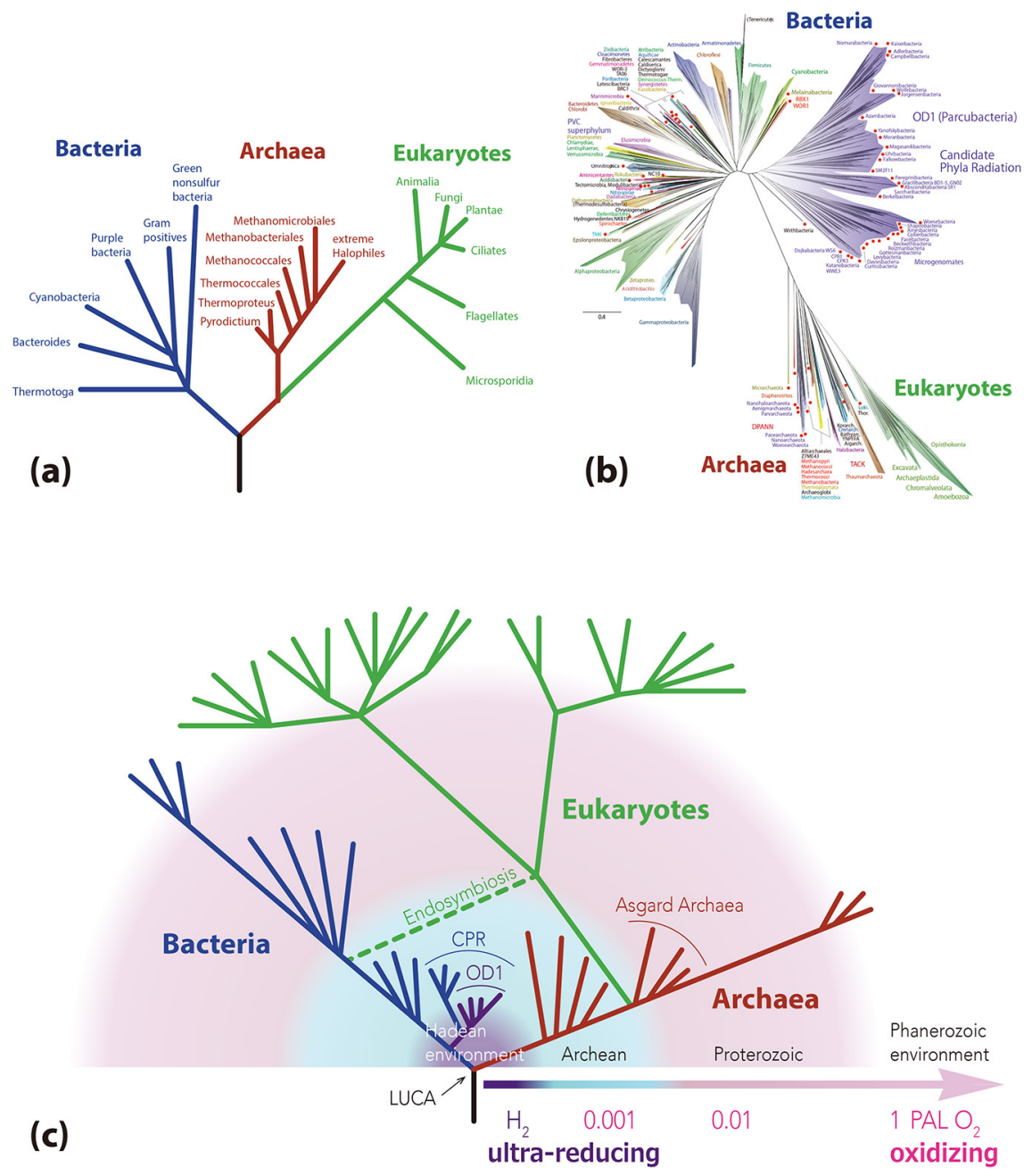

図 1 系統樹. (a) 16SrRNA 系統解析に基づく生物の系統樹（Woese et al., 1990). (b) Hug et al. (2016) による遺伝 子系統樹.（c）地球史を通して増加した大気酸素に基づく仮想的進化系統樹。中心が超還元場，周縁が（現在の 地球表層レベルの）酸素に富む環境. 環境が不変な場に生息し続ける生物は進化しない，と仮定した.

Fig. 1 Phylogenic trees. (a) Phylogenic tree by Woese et al. (1990). (b) Phylogenic tree by Hug et al. (2016). (c) Phylogenic tree based on a redox environment (oxygen level) assuming life does not evolve in an unchanged environment. The center is the ultra-reducing environment and the rim is the oxidizing environment.

始的な生命をみつけ，その生態を明らかにするこ とである。

地球上の生物は, 真核生物 (ユーカリア) ・真 正細菌（バクテリア）・古細菌（アーキア）の 3 つのドメイン（domain）に分類され，その遺 伝子系統関係を基に系統樹が描かれてきた（図 1a; Woese et al., 1990)。現生の生物のもっとも
遠い祖先にあたる最古の生命は，プロゲノート (Woese and Fox, 1977)，あるいは LUCA = last universal common ancestor (Fox et al., 1980) と呼ばれ，系統樹の根元に位置する。近年，環境 メタゲノム解析により, 新たな系統樹が提案され た（図 1b; Hug et al., 2016）。この系統樹では, 従来の $16 \mathrm{SrRNA}$ 遺伝子配列解析では把握でき 
なかった，真正細菌グループ CPR（Candidate Phyla Radiation）が追加され，真正細菌のうち $15 \%$ 以上を占める大きな多様性をもつ系統群と されている（Brown et al., 2015）。CPRに属す る未培養系統群の一つに, OD1 と呼ばれる一群 がある。最近のゲノム解読研究により, OD1の 遺伝子の数は, そのほかの真正細菌よりも極端に 少なく約 400 程度であり, もっとも原始的な生 物の一つであると考えられている。

ゲノムの系統解析によって得られる系統樹は, 解析の基準（例えば，16SrRNA）によって異な る結果を導き出している。遺伝子重複やレトロポ ゾンにより遺伝子配列のコピーがつくられると,

新しい機能を獲得して新しい遺伝子となるか, 機 能を失って偽遺伝子となる。偽遺伝子は長期にわ たる中立的な進化の果てに, 遺伝子としての体裁 を失ってしまう（Okada et al., 1997）。これが系 統の復元を困難にしている一因である。また，生 物間の共生プロセスを通じて個体間で遺伝子の平 行移動が起きることが知られ（Doolittle, 1999), 20 億年以上前にさかのぼる微生物の遺伝子系統 関係は信溤性が低い。これらのことは，複数のゲ ノム系統樹を比較することによってゲノムの新旧 を議論するのは原理的に不可能であることを意味 している。

そこで本稿では, 地球環境変動の記録と生物 の生息環境に基づいてゲノム進化を議論する。 ダーウィンの自然選択説（Darwin, 1859）は, 生物は環境の変化に応じて機能進化（適応）を起 こし，これが進化の基本原理であると説明してい る。言い換えると, 環境変化に応じて遺伝子（ゲ ノム）は変化するということである。これを裏返 すと, 環境が変わらなければ生物の進化は起きな い。つまり，ゲノム進化が起きるための環境要因 を実際の地球史記録から読み解くことによって, 地球史に基づくゲノム進化の解読が可能になる。 生命の誕生は冥王代最末期までさかのぼる証拠が ある（Bell et al., 2015; Tashiro et al., 2017）。 生物の系統樹に地質時代をあてはめてみると, 系 統樹の根元に位置する生物ほど遊離酸素のほとん どない冥王代に誕生し，系統樹の縁辺に位置する
生物ほど現代のような酸化的環境下で誕生したと 考えることができる。こうした考えに基づく仮想 的進化系統樹を，われわれは図 $1 \mathrm{c} に$ 提案する。 この図は，大気酸素の濃度を生命進化の支配要因 であると仮定し, 酸素濃度の増加とともに生物進 化がどのように進んだかを模式的に示している。

本稿では，冥王代の超還元場に類似する現在の 蛇紋岩熱水系，および，そこに生息する微生物 OD1について現在得られている情報をまとめ, それに基づき OD1 の生息にどのような地質条件 が必要かを考察する。そして, 冥王代類似環境微 生物 OD1 が地球史をどのように生き延びてきた のか，プレートテクトニクスを用いた地質学的な シナリオを新たに提案する。

\section{II. 冥王代類似環境：蛇紋岩熱水系}

\section{1）冥王代の表層環境と生命活動}

生命とは何か, と問われた時，多くの研究者は 「代謝，膜，自己複製」の 3 つの機能をもつもの として生命を定義する。生命は, 冥王代に誕生し て以来，自己複製によって子孫を残しながらも， 生命の営みとしての連続代謝反応を一度も止めた ことがない。そしてその過程において, 生命は代 謝を機能させるために，つねに電子を利用し連続 的なイオン化学反応を継続させてきた。電子を利 用することの本質的な意味は, 酸化還元電位の差 にある。生命は，生体膜の内側を超還元的に保 ち, 生体膜の外側の酸化環境との間に電位差をつ くることによって代謝反応を継続している。原始 生命はおそらく, 自然界における酸化還元電位の 差を利用した機構をそっくり模倣する形で生体に とり込んだのだと考えられる。電位差を維持する ことは, 生物の体を定常的に非平衡状態に保つと いうことであり, 非平衡であるからこそ代謝機能 がつねに進むのである。

生命の誕生は冥王代最末期までさかのぼる証拠 がある（Bell et al., 2015; Tashiro et al., 2017）。 冥王代大気は, 現在の地球大気に比べると還元的 だったとはいえ, $\mathrm{CO}_{2}$ が存在する程度には酸化的 だった。したがって，冥王代の地球表層で非平衡 状態をつくり，代謝反応を可能にするための酸化 
還元勾配を維持するには，水素発生環境の存在が 必須だったと考えられる（例えば, Martin et al., 2008; Russell et al., 2010; 戎崎ほか, in press)。 そこで，「蛇紋岩化反応」と呼ばれる岩石一水反 応が鍵となる。超苦鉄質岩に含まれる橄欖石 $\left((\mathrm{Mg}, \mathrm{Fe})_{2} \mathrm{SiO}_{4}\right)$ は，水 $\left(\mathrm{H}_{2} \mathrm{O}\right)$ と反応すること により蛇紋石 $\left((\mathrm{Mg}, \mathrm{Fe})_{3} \mathrm{Si}_{2} \mathrm{O}_{5}(\mathrm{OH})_{4}\right)$ となり, その際に水素 $\left(\mathrm{H}_{2}\right)$ を発生し, 還元環境を形成 する。還元場を作り出す蛇紋岩熱水系は, 初期地 球における水素発生場のモダンアナログとして注 目を集めている。

\section{2）現在の蛇紋岩熱水の分布と地質}

蛇紋岩熱水は, 現在の地球表層において, 海洋 底あるいは陸上のオフィオライト中に分布する (図 2 )。超苦鉄質岩は, 本来マントルを構成す る岩石である。

大西洋やインド洋の中央海嶺トランスフォーム 断層系に沿って, 蛇紋岩体が海底に大規模に露出 している。マグマからの揮発性成分の入力がない 場合，熱水噴出口ではアルカリ熱水が噴出する。 そうした環境は, 一般に, 低温 $\left(<60^{\circ} \mathrm{C}\right)$ で, 水素発生を伴う。代表的な蛇紋岩熱水系は，大西 洋中央海嶺の深海熱水噴出孔であるロストシティ (Kelley et al., 2001; Brazelton et al., 2010) お よびレインボー/ロガチェフ/アシェイズフィー ルド（Charlou et al., 2010）や，インド洋海嶺 三重点のかいれいフィールド (Hashimoto et al., 2001）である。

一方，陸上の蛇紋岩熱水は，オフィオライトと 呼ばれる海洋プレートの断片（上部マントルから 海洋地殼の岩石により構成される岩体）の一部と して陸上に露出する。オフィオライトの分布は, 基本的に沈み込み帯や大陸衝突帯の造山帯に限ら れており（図 2 ; Furnes et al., 2014），陸上の蛇 紋岩熱水系は，このようなオフイオライトが火山 フロントと交差する場でみることができる。一般 的に，陸上の蛇紋岩熱水系をつくるオフィオライ トの年代は，顕生代のものである。太古代や原生 代のオフィオライトの多くは，火山活動の起こり にくい地域に分布しており，エネルギー循環が不 活発な条件に置かれているため，蛇紋岩熱水系を
つくることができない。

陸上の代表的な蛇紋岩熱水系は，ポルトガル . カベソデビデ (Tiago and Veríssimo, 2013)，イ タリア・ボルトリ (Quéméneur et al., 2015), オマーン・セマイル (Rempfert et al., 2017), ギリシャ・オシリス（Etiope et al., 2013)，トル コ・キマイラ (Neubeck et al., 2017), カナダ・ テーブルランド (Brazelton et al., 2013)，コス タリカ・サンタエレナ (Crespo-Medina et al., 2017)，フィリピン・ザンバレス（Woycheese et al., 2015)，ニューカレドニア・プロニー湾 (Quéméneur et al., 2014)，ニュージーランド・ ポイズン湾 (Wood, 1972), 米国・コーストレン ジ (Twing et al., 2017), シダーズ (Suzuki et al., 2017), そして日本・白馬八方 (Suda et al., 2014, 2017）などである。なかでも白馬八方の蛇 紋岩体は，他のオフィオライトに比べて比較的古 い約 6 億年前に原日本島弧に付加し，現在は火 山フロントの熱エネルギー循環の及ぶ範囲に位置 している，稀な地質学的条件下にある。

これら世界各地の蛇紋岩熱水系では，エネル ギー物質循環および微生物群集の解析が行われて いる。 $\mathrm{pH}$ や温度といった物理化学的な条件が微 生物叢と密接に関わっていることはすでに指摘さ れてきた。しかし，地質学的にその蛇紋岩体の来 歴まで含めた議論はいまだされていない。そこで, 本稿では，「冥王代類似環境」である蛇紋岩熱水 系の地球史における時空間分布を地質学的に復元 し，原始的な非平衡場である水素発生環境におい て誕生し，同様の環境で棲息し続けてきたであろ う微生物 OD1 について論じる。

\section{III. 冥王代類似環境微生物：OD1}

\section{1）OD1 とは}

OD1 は，真正細菌のなかの 1 つの系統群であ る。従来，微生物のゲノム解析は単離・培養を 経てゲノム DNAを調製する必要があったが，近 年，メタゲノム解析により，環境中のゲノムを網 羅的に配列解析することが可能になった（例えば, Venter et al., 2004)。また，シングルセルゲノム 解析により，単一ないしごく少数の細胞からゲノ 


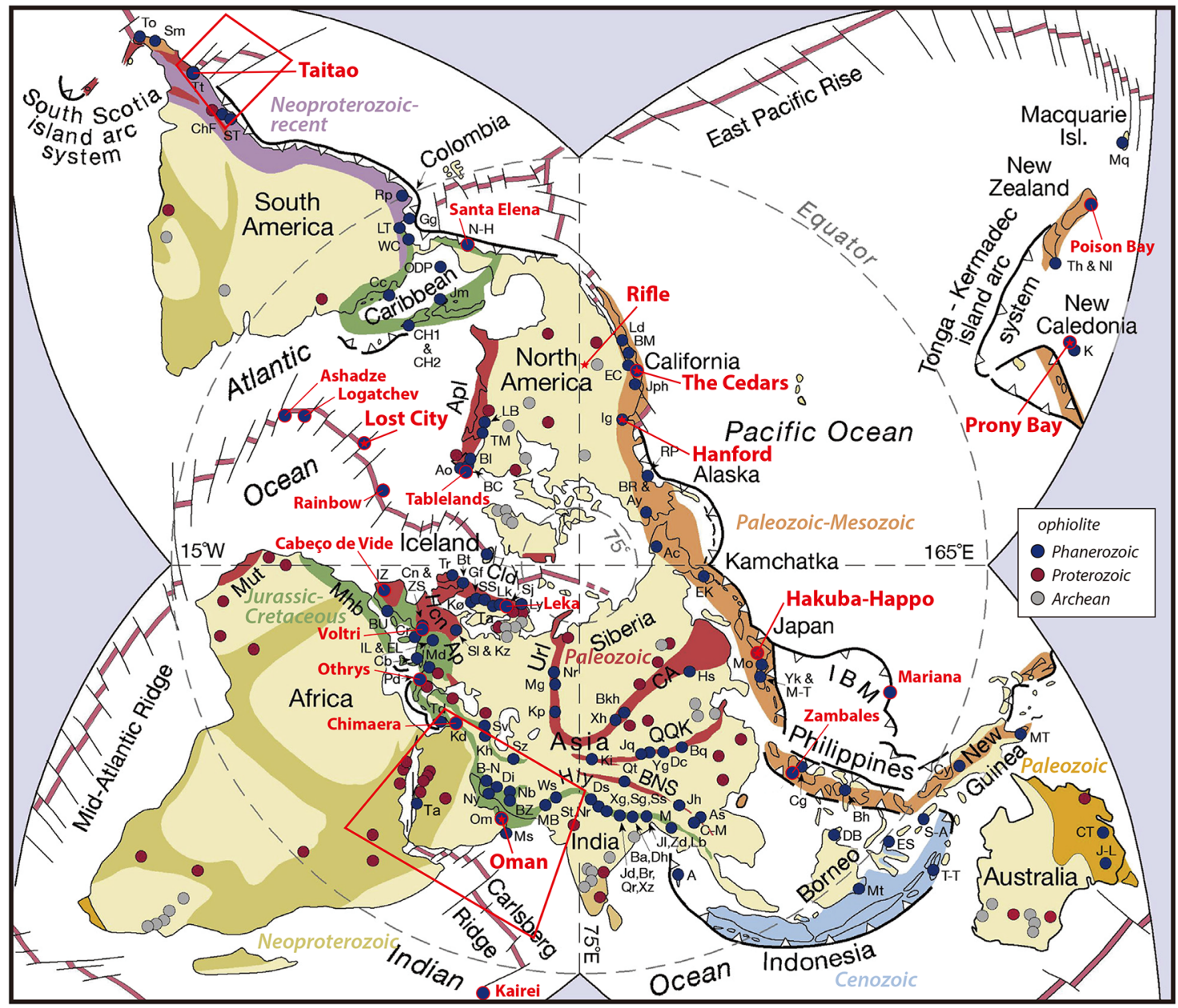

図 2 オフィオライトと蛇紋岩熱水系の分布 (Furnes et al., 2014 を改変). 大西洋中央海嶺, インド洋海嶺三重点のほ かに陸上の造山帯のなかにトラップされている蛇紋岩体の分布. 顕生代のオフィオライトが大部分を占めるが,

これらのなかで白馬八方蛇紋岩熱水系は橄欖岩が約 5.8 億年前に陸へ付加し，現在の島弧火山フロントと偶然 交差する特異な地域である.

Fig. 2 Distribution map of ophiolite and serpentinite-hosted hydrothermal systems (modified from Furnes et al., 2014), including Atlantic mid-oceanic ridges, Central Indian Ocean Triple Junction, and on-land serpentinite-hosted hydrothermal systems trapped in orogenic belts. Among these places, the Hakuba-Happo serpentine-hosted hydrothermal system is a unique crossroad of the volcanic front of the island arc and peridotite accreted in $c a$. $580 \mathrm{Ma}$.

ム配列を復元することが可能になった（例えば， Yoon et al., 2011)。さらに, メタゲノム中の配 列断片をグループ化して個々の微生物ゲノムを再 構築する，ゲノムビニングと呼ばれる解析手法が 確立された（例えば, Albertsen et al., 2013）。こ れらの技術革新により，未培養の微生物の系統分
類が行われるようになり，真正細菌の新たな系統 群が明らかになってきた。Paceらのグループは, Yellowstone の Obsidian Pool において 12 の新 系統群（candidate division）を発見し，おのお の「OP1〜 OP12」と命名した (Hugenholtz et al., 1998)。そして, OP11をさらに5つの系 
統群に細分化し，その1つを「OD1」（OP11Derived 1：OP11 から派生した系統群その 1) と名づけた（Harris et al., 2004）。その後，国 際共同研究グループによって OD1 のゲノムが解 読され，OD1は「Parcubacteria」（つましいバ クテリア）と命名された（Rinke et al., 2013）。

Banfield らのグループは，35 の門に相当する未 培養系統群を Candidate Phyla Radiation (CPR) と総称し，CPR を含めた新たな系統樹を提案し た（Brown et al., 2015; Hug et al., 2016)。彼ら はOD1 を上門 superphylum と位置づけ，それ ぞれ門に相当する系統群へ細分化し，著名な微生 物学者の名前をもとに命名を試みた。本稿では, OD1 = Parcubacteria に相当する真核細菌群を $\lceil\mathrm{OD} 1 」$ と呼ぶことにする。

\section{2）OD1 の報告例}

これまでに, OD1は世界各地の蛇紋岩熱水や土 壤などの環境から報告されている（表 1 , 図 3 )。

深海底の蛇紋岩熱水系として, 大西洋中央海嶺・ ロストシティにおいて，750 m 深の炭酸塩チム ニーでは $14 \mathrm{mmol} / \mathrm{kg}$ という比較的高い水素濃度 が保たれており，OD1が報告されている（Kelley et al., 2001, 2005; Brazelton et al., 2010; Lang et al., 2012)。Brazelton et al.（2010）は，海水 組成や温度よりも，むしろチムニーの鉱物組成お よび年代が，微生物生態をコントロールしている と指摘している。より深い海底環境からは，マリ アナ海溝の最深部・チャレンジャー海淵（10,920 $\mathrm{m}$ 深）の堆積物中からも OD1 が報告されている (León-Zayas et al., 2017)。一方, 浅海の蛇紋岩 熱水系として，ニューカレドニア・プロニー湾 において, 水深 $50 \mathrm{~m}$ 以下の浅い炭酸塩チムニー から OD1 が報告されている（Quéméneur et al., 2014; Frouin et al., 2018)。

陸上の蛇紋岩熱水として, 米国カリフォルニア 州の北部に位置する蛇紋岩地帯の湧水池シダー ズが注目を集めており，フランシスカン層群に 伴う蛇紋岩岩体の渓谷に沿って流れ出る地下水 (常温)に OD1 が生息している（Morrill et al., 2013; Suzuki et al., 2013, 2017)。OD1 が全微生 物量の $70 \%$ を占め, ゲノムサイズは $445 \mathrm{kbp}$ と
非常に小さい。測定された溶存酸素量は非常に低 く, 高い水素濃度と調和的である。蛍光顕微鏡に より，橄欖石あるいは蛇紋石の表面に分布するき わめて小さい（約 $0.3 \mu \mathrm{m} ）$ 球状の細胞が確認さ れた（Suzuki et al., 2017）。シダーズと比較的 似た陸上蛇紋岩熱水系として，イタリア・ボル トリにおいては, OD1 が全微生物量の $21 \%$ を占 める (Quéméneur et al., 2015; Brazelton et al., 2017)。蛇紋岩そのほかに, オマーン・オフィオ ライトの橄欖岩体の掘削井戸 (100-400 m) から も，OD1 が報告されている (Neal and Stranger, 1983; Rempfert et al., 2017） が, 全微生物量の うち $5 \%$ のみを占める。日本の長野県白馬地域 の巨大蛇紋岩熱水系の深度 500-700 m の井戸か らくみ上げた温度約 $50^{\circ} \mathrm{C}$ の熱水 (Suda et al., 2014, 2017）は，定常的に水素を発生させる超還 元環境であり, 冥王代の生命誕生場に類似した環 境である。そこから発見された OD1の遺伝子は, 真正細菌に属しながらも, 古細菌の特徴をあわせ もっている(戎崎ほか, in press)。特殊な例とし て，ノルウェーのレカ・オフィオライトでは，夕゙ ナイト岩体へ天水がしみ込んでいるだけ（熱水系 などの熱エネルギー循環が不在）にも関わらず CPR 細菌が発見される (Daae et al., 2013)。工 ネルギー物質循環が強く駆動されていない場合で も，CPR 細菌の棲息は可能であり，生き延びる ことはできると推測される。

陸上の非蛇紋岩熱水においても, 米国ワシント ン州ハンフォード (Lin et al., 2012; Nelson and Stegen, 2015）およびコロラド州ライフル地域 （Luef et al., 2015; Danczak et al., 2016）の地下 水から OD1 が報告されている。ハンフォードに 棲息する OD1 の解析によると，ゲノムサイズは 非常に小さく $(<1 \mathrm{Mb})$ ，コア遺伝子の数は 202 個しかない（Nelson and Stegen, 2015)。さら に，アミノ酸，ヌクレオチド，脂肪酸の生合成 に必要な遺伝子群が久落している。そのため, OD1は他の生物に寄生または細胞外共生体とし て生活していると推測されている。ライフルの OD1 は, クライオ透過型電子顕微鏡で観察され, 約 $0.009 \mu \mathrm{m}^{3}$ のきわめて小さい細胞であること 


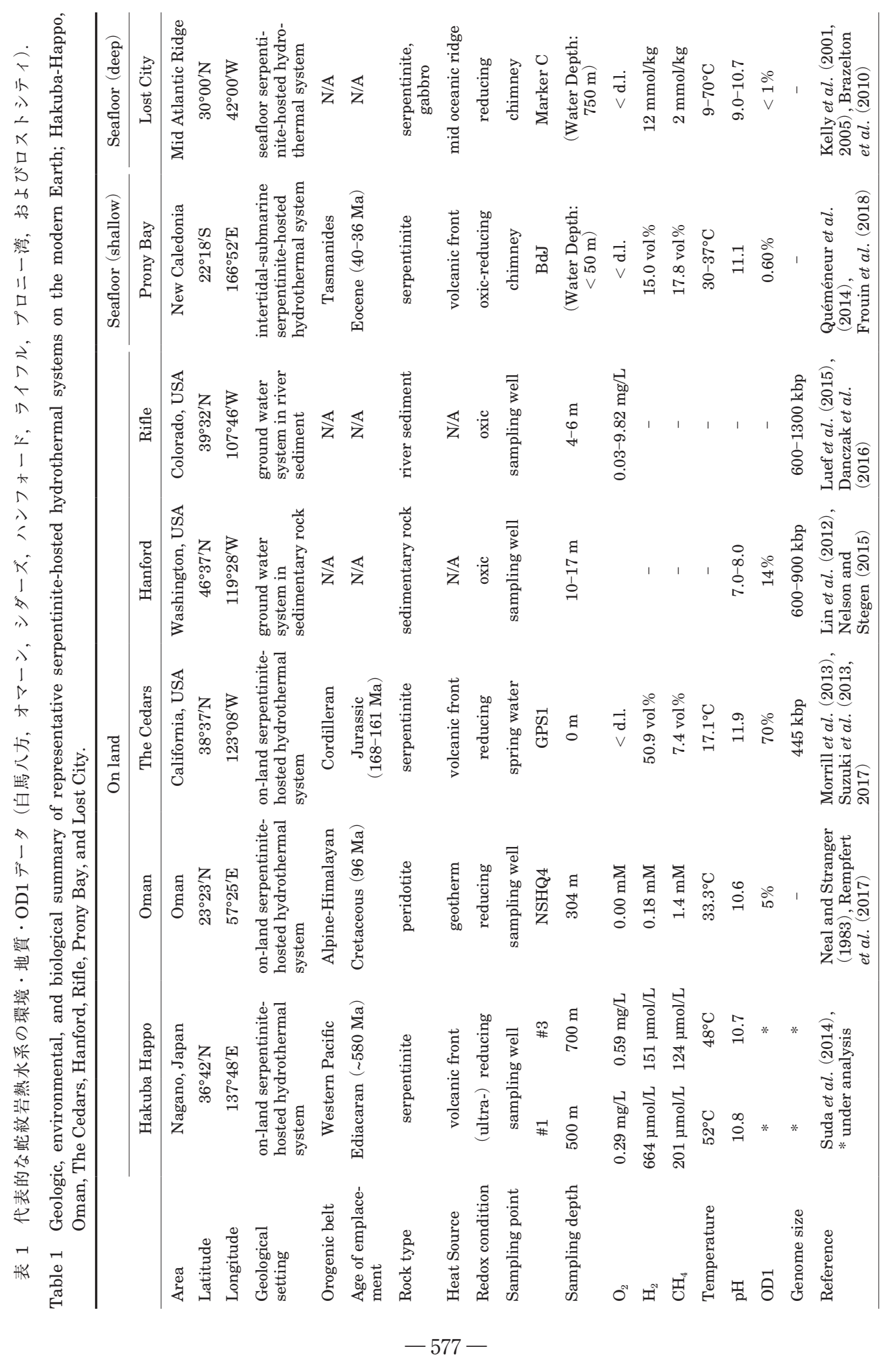




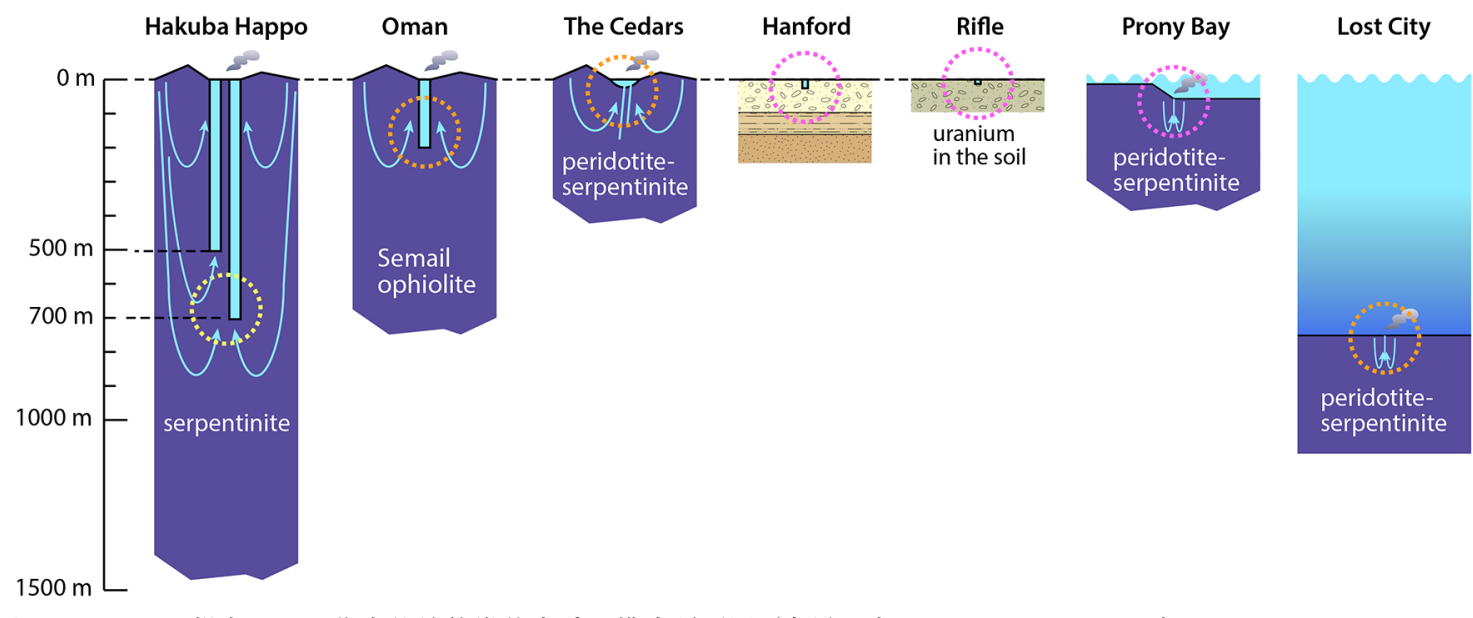

図 3 OD1が報告された代表的蛇紋岩熱水系の模式断面図（白馬八方，オマーン，シダーズ，ハンフォード，ライフ ル，プロニー湾，およびロストシティ). 造山帯中にトラップされた超苦鉄質岩に伴う水の循環系が生まれると， 超還元場が生まれる。オマーン，シダーズ，ハンフォード，ライフルに比べて，白馬八方の蛇紋岩熱水系は， 500-700 m深度まで掘削され， $50^{\circ} \mathrm{C}$ の温泉水が噴出し， 25 年以上安定した熱水循環系として機能してきたので, 表層の微生物などの混染を無視できる蛇紋岩熱水系である.

Fig. 3 Schematic cross-sections of serpentinite-hosted hydrothermal systems: Hakuba-Happo, Oman, The Cedars, Hanford, Rifle, Prony Bay, and Lost City. Ultra-reducing environment is achieved when water circulation occurs with ultramafic rocks trapped in the orogenic belt. Compared to Oman ophiolite, The Cedars, Hanford, and Rifle, the source of the Hakuba-Happo hydrothermal system (500-700 m deep in the serpentinite block) is in the most ultra-reducing environment, and $50^{\circ} \mathrm{C}$ water has been welling up stably for more than 25 years; namely, contamination of microbes from the surface can be excluded.

が判明した（Luef et al., 2015）。この両地域は核 廃棄物処理施設としての歴史があり，特異な性質 をもつ微生物 OD1 が核廃棄物と関係して生まれ たと推測されたことがある。

\section{3) OD1 の特徵}

上記の地域から報告された OD1の重要な特徵 を，以下にまとめる。

(i) ゲノムサイズがきわめて小さい。いずれの 地域から報告された OD1も，1 Mbp 以下のゲノ ムサイズであり，とくにシダーズの OD1のゲノ ムサイズは，約 $445 \mathrm{kbp}$ である（Suzuki et al., 2017)。

（ii）膜・自己複製の遺伝子はもつが，代謝の 遺伝子をもたない。Nelson and Stegen（2015） は，ハンフォードの OD1 が共生していると考え た。その後, Suzuki et al. (2017) は, シダーズ において OD1 が微生物叢の $70 \%$ 以上を占めるこ とから，単純な共生ではない可能性を指摘した。 （iii）真正細菌と古細菌の両方の特徴をもつ。 OD1 が真正細菌でありながら古細菌型のゲノ ムをあわせもつことに対し, León-Zayas et al. （2017）は，古細菌由来の遺伝子を水平伝播によ り獲得したと解釈したが，戎崎ほか（in press） は，真正細菌と古細菌の共通祖先に近い存在であ ると考えた。

（iv）高アルカリ，超還元環境ほど，微生物叢 に占める OD1 の割合が大きい。橄欖石の表面に 分布することが確認され，蛇紋岩化反応により発 生する水素をエネルギー源として生きていると考 えられる (Suzuki et al., 2017)。

これらの特徵のなかで，とくに OD1のゲノム サイズは，一般的な真正細菌である大腸菌のゲノ ムサイズ (4.6 Mbp; Blattner et al., 1997) の約 10 分の 1 しかなく, OD1 を「常識はずれな微生 物」として特徴づけている。一般に, ゲノムサイ ズが小さいということは，「進化していない」あ 
るいは「不要なゲノムを捨てた」ことを示す。例 えば，真正細菌の一属であるマイコプラズマは, 真核生物を宿主とする寄生生物であり，細胞壁や TCA 回路にまつわる不要な遺伝子をもたないこ とにより，小さなゲノムサイズ（580 kbp）を達 成している（Fraser et al., 1995）。OD1は，代 謝にまつわる遺伝子に欠損があるものの，マイコ プラズマと違って特定の生物に寄生している兆候 はみられない。OD1のきわめて小さいゲノムサ イズは，OD1が原始的な生命に近い存在である 可能性を示唆する。

本稿では，OD1に対し，地質学的な視点から 生命進化における位置づけを試みる。次章では, 白馬八方温泉を例に, OD1 生息に必要なエネル ギー物質循環系の条件および地質学的背景を考察 する。

\section{IV. 白馬八方蛇紋岩熱水の地質と OD1 生息条件}

\section{1）白馬八方蛇紋岩熱水の地質}

長野県西部に位置する白馬岳地域 $\left(36^{\circ} \mathrm{N}\right.$, $\left.137^{\circ} \mathrm{E}\right)$ は，地体構造区分では飛騨外縁帯に属 し，古生代の基盤岩は超苦鉄質岩，広域変成岩， 堆積岩からなる（図 4 ）。超苦鉄質岩はおおむね 蛇紋岩化しているが，一部に八方・岩竹山地域の ように新鮮な橄欖岩が $1 \mathrm{~km}$ 程度の小規模なレン ズ状岩体として残る部分も存在する。蛇紋岩体は 約 $10 \mathrm{~km} \times 10 \mathrm{~km}$ の広がりをもち，厚さは $3 \mathrm{~km}$ 以上と推定される。白馬岳地域の蛇紋岩は，南中 国地塊が超大陸ロディニアから分裂した後，縁辺 の受動的大陸縁が活動的大陸縁へと転化した際に 大陸側にとり残された海洋リソスフェアの断片と 解釈される（図 4c; 磯崎・丸山, 1991; 磯㟝ほか, 2011)。糸魚川-青海地域の蛇紋岩体中のヒスイ

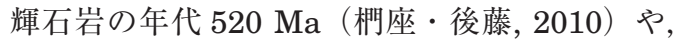
九州西部の変はんれい岩体中の角閃岩の年代 583 Ma（猪木ほか, 1979）から類推すると，白馬蛇 紋岩体の搬入年代はカンブリア紀あるいはエディ アカラ紀までさかのぼると考えられる。糸魚川一 静岡構造線沿いに, 白馬岳地域を含め, 南北に 活動的な温泉が点在している（竹内ほか, 2004; Homma and Tsukahara, 2008)。
この白馬岳地域において，白馬八方，蓮華，若 栗, 相池, 鞍下の 5 つの主要な温泉が点在する。 このうち白馬八方 $\left(36^{\circ} 42^{\prime} \mathrm{N} ， 137^{\circ} 48^{\prime} \mathrm{E}\right)$ は，蛇 紋岩体の直上に位置し (図 4 ), $\mathrm{pH}$ が 10 を超え る，日本でもっとも高アルカリ性の温泉として知 られる。水温は約 $50^{\circ} \mathrm{C}$ 程度で，水素ガスを多く 含む（Tsukuda, 2000; Suda et al., 2014, 2017)。

白馬八方温泉の地下構造と物質循環は, 図 $4 \mathrm{~b}$ に示される。日本海から南側に流れる雲が北アル プスの山脈にぶつかり，降雨あるいは降雪ののち 雪溶け水として，蛇紋岩体に浸透する。その際 に，累重する火山灰層や蛇紋岩体内部に捕獲され ている花崗岩質な堆積岩或は土壌からの有機物を 蛇紋岩体の深部へ断層沿いの割れ目に沿って輸送 する。地下水は火山フロントの熱源により温めら れ，上昇に転じて湧水熱水帯を形成する。白馬八 方温泉の温泉井は，地表から 500-700 m の深さ から水をくみ上げている。そのなかに，微量の 微生物が含まれ，メ夕ゲノム解析により OD1 が 発見された（戎崎ほか, in press）。

\section{2）OD1 の生息に必要な 3つの条件}

白馬八方温泉の地質および熱水循環をみると, OD1の生息には，無酸素の超還元場，栄養塩の 供給，そして物質循環の駆動力の 3 つの条件が 必要であると考えられる。

\section{2-1）無酸素の超還元場}

白馬八方温泉で発見された OD1の生息環境 は，無酸素の超還元場である。これは，断層の割 れ目に沿って表層から侵入する水が超苦鉄質岩 の橄欖石 $\left((\mathrm{Mg}, \mathrm{Fe})_{2} \mathrm{SiO}_{4}\right)$ と反応して蛇紋岩化 (蛇紋石 $\left.(\mathrm{Mg}, \mathrm{Fe})_{3} \mathrm{Si}_{2} \mathrm{O}_{5}(\mathrm{OH})_{4}\right)$ し，その時に $\mathrm{H}_{2}$ ガスを放出するからである。表層から降下する天 水のなかに溶存する酸素は, 水素と反応して水に なるため，遊離酸素が消費される。そうした環境 では，蛇紋岩化作用が定常的に進むと水素が生産 されつづける。このような「水素ポンプ」の機能 が働き続ける限り，水素イオン濃度は高く保た れ，またブルース石 $\left(\mathrm{Mg}(\mathrm{OH})_{2}\right)$ が溶脱すると アルカリ環境の超還元場が維持される。しかし, 水素ポンプが機能しなくなると，超還元状態から 普通の還元状態へ戻る。 


\section{2-2）栄養塩の供給}

ある系のなかで生物が生息し続けるためには, エネルギーの供給ともに，栄養塩や有機物の定常 的な供給が必要である。蛇紋岩のなかには生物に 必要なリンやカリウムなどの必須元素が枯渇して
いるので，これらの栄養塩元素は蛇紋岩以外の岩 石から水とともに供給されねばならない。つまり， 水と栄養塩元素の一部は系の外部からの供給とな る。陸上蛇紋岩熱水系の場合, 現在の陸上は植生 や土壤に覆われているため, 少なからず地下水へ
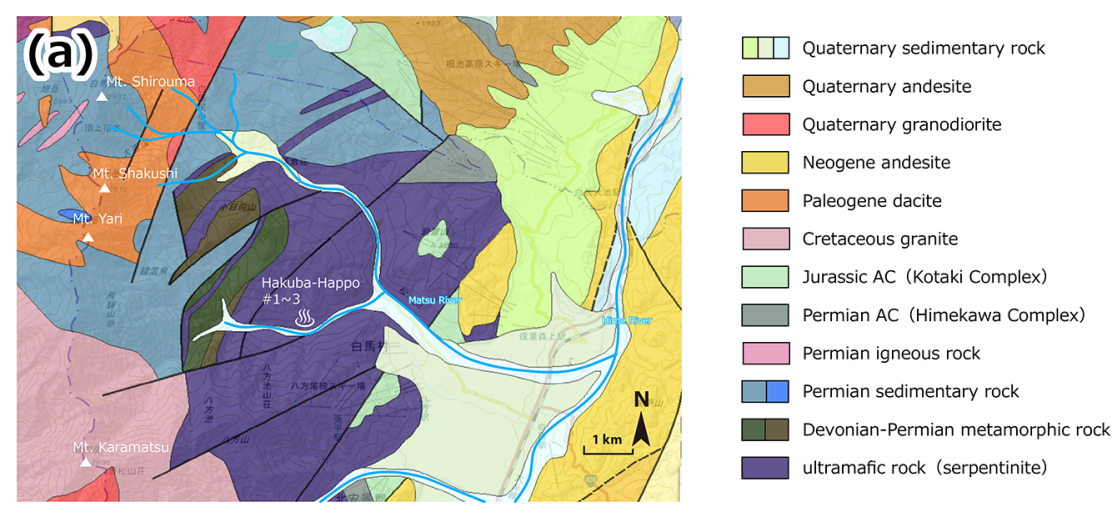

(b)

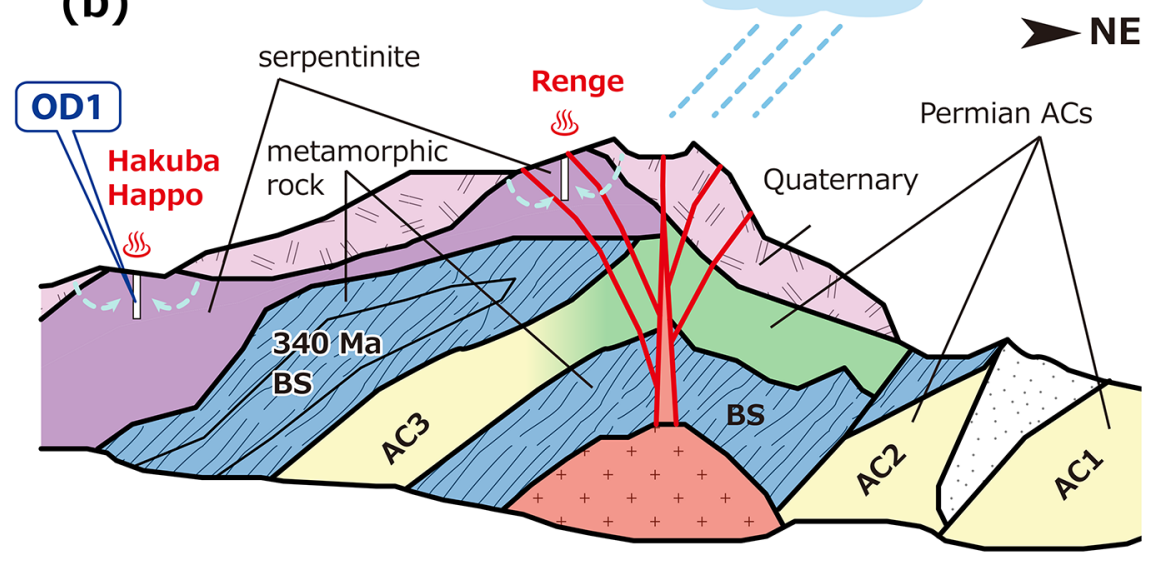

(c)

Cambrian arc-trench system

proto-Japan arc

(TTG crust)

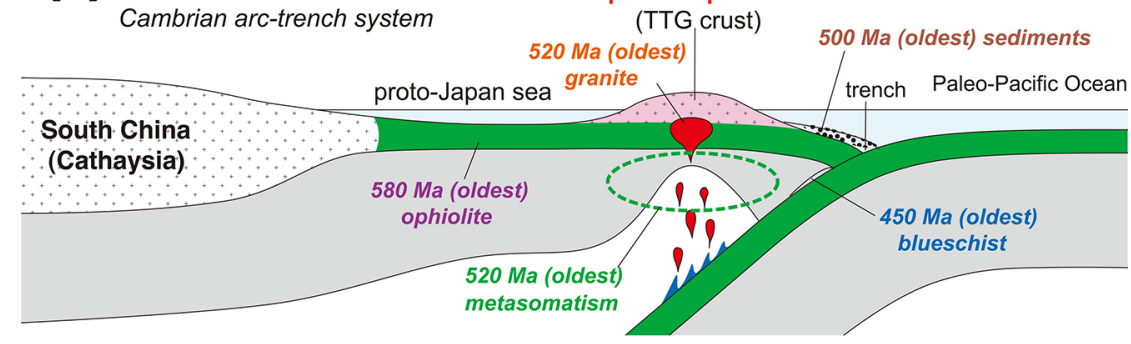

図 4

Fig. 4 
の有機物の供給は保障されている。深海蛇紋岩熱 水においても, 沈降有機物由来の無機栄養塩類が 消費されずに残っている。一方で，無機栄養塩元 素の種類に加えて，その元素がどのようなイオン 状態にあるのかが鍵である。例えばリンはさまざ まなイオン状態が可能だが，超還元状態ではきわ めて反応性に富む $\mathrm{PO}_{4}{ }^{3-}$ の状態にあると考えら れる (Mulkidjanian et al., 2012)。

\section{2-3) 物質循環の駆動力}

生物が生き続けるためには物質循環によってエ ネルギーと物質が供給されることが必要不可欠で あり，そのための駆動力がなければならない。白 馬地域の場合，駆動力は地下深部マグマからの熱 がそれを担っている。しかし，注意しておきたい のは，マグマの揮発性成分である硫化水素が系の なかに侵入すると，熱水は強酸（ $\mathrm{pH}<2 ）$ にな ることである。これは白馬地域北方の高温の温泉 にみられ，こうした環境では OD1の棲息は難し い。例えば，蛇紋岩岩体の上部に噴出している温 泉（蓮華温泉）であっても，強酸の熱水環境で OD1 は見つかっていない（図 4)。そのほかの地 域でも，火山フロントのマグマからの熱や，地熱 により水循環が駆動されているが，ハンフォード やライフルでは，熱の供給はみられない。このこ とは，多少，熱の供給が弱い環境下においても，
OD1 が細々と生き延びることは可能であること を示す。

以上 3 つの条件は，現在の蛇紋岩熱水だけでは なく, 過去の地質時代の蛇紋岩熱水でも達成可能 であった。例えば，太古代には超苦鉄質火山岩で あるコマチアイトが海底で噴出し，海底熱水反応 を被っている（Shibuya et al., 2010）。蛇紋岩化 反応は，太古代，さらには冥王代までさかのぼっ ても起こっていた（Takai et al., 2006; Shibuya et al., 2015)。言い換えると, OD1 が生きてゆけ る環境は冥王代にすでに存在していたと考えられ る。ただし，地球表層はこれまで過酷な環境変動 (とくに酸素濃度の上昇)を経てきた。そのなか で，OD1 は生き延びることができたのか，時間 軸を追って復元を試みる。次章では，その前提と して，進化のメカニズム，すなわち生物進化と環 境変動の関倸について整理したい。

\section{V. 生物進化と酸化還元環境}

OD1の多くが蛇紋岩熱水系において発見され ているという事実は，OD1 が蛇紋岩化作用によ り水素が定常的に供給される超還元場に適応して いるということを示す。進化論の基礎となる自然 選択説（Darwin, 1859）は，「環境の変化が生物 進化をもたらす」という考えである。環境の変化

図 4 (a) 白馬地域の地質図扔よび (b) 白馬八方温泉熱水系の模式断面図（産業技術総合研究所地質調査総合セン ター, 2015 を改変)。白馬最大の蛇紋岩岩体上，松川の支流（南股入）沿いに掘削井 \#1-3（500-700 m深度）が位 置し，温泉を地下 $500 \mathrm{~m}$ から引き上げている．天水が蛇紋岩体へ入り，火山フロントの熱で温められて熱水系 をなす。リンは蛇紋岩体に累重する凝灰岩層や土壤からもたらされる。蛇紋岩化作用により温泉井戸深部にお いて水素ガスが発生し，蛇紋岩带の深部に限られた特異な部分的に外部に開いた開放系として超還元環境が保 たれている。（c）エディアカラ紀-カンブリア紀の日本の模式断面図（磯㠃ほか, 2011）。原日本は，南中国地塊 の縁辺の海洋島弧として誕生した．南中国と島弧の間には，小さな海洋地殼が存在し，その断片が白馬八方地 域に日本最古オフィオライト（約 $580 \mathrm{Ma})$ として残されている. 同じ飛騨外縁带の最古熱水変質岩 $(520 \mathrm{Ma})$ も原日本弧誕生時の痕跡である.

Fig. 4 (a) Geologic map of Hakuba area and (b) schematic cross-section showing Hakuba-Happo hydrothermal system (modified from AIST, 2015). Drilling holes \#1-3 (500-700 m deep) are located along a branch of the Matsukawa River (Minami-Matairi) on the largest serpentinite block, and hot water is pumped up from $c a .500 \mathrm{~m}$ deep in the serpentinite. Meteoric water infiltrates the serpentinite block in Hakuba, and heat from the volcanic front warms it up to make the hydrothermal system. Phosphorus is supplied from overlying tuff and soil. Serpentinization provides hydrogen gas deep in the well, and an ultra-reducing environment is maintained only at the deep part. (c) Schematic profile of passive margin of South China in the Ediacaran-Cambrian. The oceanic crust between South China and proto-Japan arc is partially preserved at Hakuba-Happo as the oldest ophiolite $(\sim 580$ $\mathrm{Ma})$ in Japan. The oldest metasomatism $(520 \mathrm{Ma})$ recorded in the Hida Gaien Belt also occurred within this proto-Japan arc system. 
への生物の応答こそが進化であるとすれば，「環 境が変わらなければ進化は起こらない」。OD1の 棲む超還元場は，地球史を通じてつねに地球表層 の特定の場所に存在していた。OD1は，40 億年 前から超還元場に棲息し続けたため，ほとんど進 化せず原始的なまま（ゲノムサイズが小さいまま） 生き残った冥王代の「生きた化石」である可能性 がある。

\section{1）ダーウィン進化と OD1}

ダーウィンの自然選択説（Darwin, 1859）は, 変化する生息環境のなかで，有利な形質を獲得し た生物が生き残り，それ以外の生物が死滅する， という進化のメカニズムの提案である。この考え を裏返すと，環境がきわめて安定した場所では， そこに生息する生物は進化しないといえる。ダー ウィン自身は，ゆっくりとした環境の変化への適 応を想定し，「大量絶滅」を伴うような極端な環 境変動の存在は信じていなかった。しかしその 後，大型化石を多産する顕生代（約 5 億 4000 万 年前〜現在）の化石記録が統計学的に意味をもつ ようになり，5 回の大量絶滅が起きたことが明ら かになった（例えば, Sepkoski, 1984）。ダーウィ ンの考えていたような漸進的な一定速度の進化で はなく，大量絶滅の前後で進化速度が加速した可 能性を考慮しなければならない（Ebisuzaki and Maruyama, 2015)。

地球史を通した生態系のなかで，環境がもっと も安定している場所は中央海嶺熱水系である。な ぜなら，地球表層が例え全球凍結の状態であって も，中央海嶺熱水系は下部からのマグマの熱の供 給により安定したエネルギー物質循環が保たれる からである。ただし，中央海嶺で供給される栄養 塩の種類と量には制限があるので，この環境で棲 息する生物たちは，ごく少量の栄養塩を選択的に とり入れる術をもっている。

これに対し，環境が激しく変化するのが地表 （地上および浅海）である。それは，地表が宇宙 に対して「剥き出し」の状態にあり，とくに太古 代では大気酸素濃度が低いため防護壁となるオゾ ン層がなく，さらに冥王代は約 42 億年前になる まで強い地球磁場さえなかった（Tarduno et al.,
2015）からである。地球史を通じて，地表は多 種多様な環境変動にさらされてきた。例えば，ス ターバーストが原因で引き起こされる全球凍結 （例えば, Kataoka et al., 2014）や太陽系と暗黒星 雲との衝突に伴う極端な寒冷化（例えば, Nimura et al., 2016)，小惑星の衝突に伴う寒冷化（例え ば, Alvarez et al., 1980)，スーパープルームの 上昇に起因する磁場の擾乱と強度低下（例えば, Isozaki, 2009), 大規模火山活動（例えば, Keller, 2005）などである。とくに酸素発生型光 合成生物の出現による大気酸素の増加は，地表の 生物にとっての生息環境を劇的に変え，生物は真 核生物，さらには大型多細胞生物へと著しい進化 を遂げた。

地表で起きた大環境変動をほとんど経験しな い，あるいはきわめてわずかな影響しか被らなかっ た場所が中央海嶺熱水系である。地球上でもっと もゲノムの小さい微生物群である OD1 は，その ような中央海嶺熱水系の水素発生場において，淘 汰圧にさらされることなく，冥王代から現在まで 綱渡りのように生き継いだと推察される。

\section{2) 還元環境から酸化環境への適応の不可逆性}

冥王代に生命が誕生した後，さまざまな進化の 結果シアノバクテリアが出現し酸素発生型の光合 成を行うようになった。酸素環境の出現に伴っ て，生物の代謝，膜，自己複製の機能は次第に複 雑かつ大規模になり，約 23-22 億年前頃の真核 生物誕生を経て，原生代末期に大型多細胞動物が 出現した。酸素環境に適応した真核生物および多 細胞動物は, 酸素環境でのみ生息可能であり，超 還元場では生存することができない。このこと は，還元環境から酸化環境への適応進化を逆戻り することができないという「進化の不可逆性」を 意味している。その原因は，酸素を利用しはじめ た生物は酸素によってより巨大なエネルギーを獲 得し，生物の体積を桁違いに大きくしたことにあ る。いったん巨大化した真核生物および多細胞動 物は，十分な量の酸素供給が絶たれると，生命を 維持し続けることができない。これは，酸素環境 適応進化の不可逆性といえるだろう。例外的に海 底熱水噴出孔に生息する多細胞動物であるチュー 
ブワームは，一見，無酸素環境に適応進化したよ うにみえるが，化学合成細菌と共生することに よりエネルギーを得ている (Cavanaugh et al., 1981）ため，独立した生命体として無酸素環境 に適応しているわけではない。

こうした進化の不可逆性に基づくと，酸化場に 適応した生物は原生代以後に出現し, 還元場に適 応した生物は太古代以前に出現したと考えること ができる。この考えに基づき，環境変動を基準に 生物系統の整理を試みたのが図 1c である。現代 もなお地下の蛇紋岩熱水系の水素発生場に棲息し ている OD1 は，冥王代のころのままほとんど進 化していない，もっとも原始的な微生物，すなわ ち「40 億年前の生きた化石生物」と考えること ができる。ただし，OD1 は現代まで生き延びる 間に，いくつかの遺伝子を廃棄した可能性が残 る。また，OD1 は，分子系統に基づき 15 以上の 門に細分される（Brown et al., 2015）。これまで に報告された OD1の生息場における酸化還元環 境の多様性を考慮すると, 冥王代に類似した還元 環境で生き続けている OD1のほかに, 酸化的環 境にさらされてしまい原初的な性質を保持してい ないOD1 も存在すると考えられる。

\section{3）生きた化石生物}

進化が停止したようにみえる「生きた化石生 物」の例として，シーラカンスがあげられる。シー ラカンスは，デボン紀からほとんど姿を変えず, 現在はコモロ諸島やインドネシアの海域に棲息し ており，ゲノムからも進化速度が遅いことが示さ れている (Amemiya et al., 2013)。シーラカン スは，深海環境に棲息していることより，表層の 環境変動の影響が少なかったため, 約 4 億年たっ ても大きな進化をしなかったと考えられる。深海 生物に「生きた化石」と呼ばれる種が多いのはこ のためである。

多細胞動物だけではなく, 真核単細胞生物や古 細菌，真正細菌にも「生きた化石生物」は認めら れる。近年発見された，真核生物にもっとも近い 古細菌グループの「アスガルド古細菌」も，「生 きた化石生物」といえる。北極海ガッケル海嶺の 熱水系において, 古細菌の未分類系統群がみつか
り，メタゲノム解析から，真核生物と古細菌の中 間的な性質をもっていることが明らかになった (Jørgensen et al., 2012, 2013)。門に相当するこ の系統群は，発見された Loki's Castle 熱水系に ちなんで「ロキ古細菌（ロキアーキオータ）」と 名づけられた（Spang et al., 2015）。その後，世 界数か所からロキアーキオータに似た古細菌群が みつかり, 北欧神話にちなんでトール古細菌, オー ディン古細菌，へイムダル古細菌と名づけられ， これらの系統をあわせて「アスガルド古細菌系 統」と総称された（Seitz et al., 2016; ZerembaNiedzwiedzka et al., 2017)。これらの古細菌は, いずれも嫌気的環境に棲息し，未培養であるが, 真核生物誕生における実験モデル生物として, 今 後の研究が期待される。

OD1 は，このような「生きた化石生物」のな かでも，冥王代から生き続けている「40 億年前 の生きた化石生物」とみなすことができる。一方 で，二次的に不要な遺伝子を失った可能性も考え られるが，いずれにしても OD1は冥王代類似環 境で生存可能な微生物として重要である。次章で は，OD1を「生きた化石」と解釈した場合，本 当に環境不変の場所に居座り続け, 地球史を生き 延びることができたのか, 地質学的に検証を行う。

\section{OD1 の生息環境の綱渡りの歴史 : 冥王代から現代まで}

OD1 が冥王代に誕生し超還元場で生き延びて きたとすれば，彼らは地球環境の変化をどのよう に乗り越えてきたのだろうか? 生物は, 一度酸 化環境に適応し，反応性に富む $\mathrm{O}_{2}$ を利用するよ うになると， $\mathrm{O}_{2}$ のない還元環境へ戻ることが困 難である。すなわち，OD1 は冥王代に誕生して 以来一貫して超還元場に棲息してきたはずであ る。一方で, 地球誕生以来の表層環境変化を振り 返ると，冥王代に存在した表層の還元環境は徐々 に少なくなり，いくつかの限られた場を除いて， 現在に至るまでにほぼ消失した。少なくとも現在 の大陸表層および海洋は遊離酸素に満ちている。 OD1はどのように超還元場を渡り歩き，かつ進 化を免れたのか，以下に，プレートテクトニクス 
を用いた地質学的観点から，その機構を論じる。

\section{1）冥王代のマントル橄欖岩}

冥王代の地質記録は，ごくわずかなジルコンの 結晶粒 (Wilde et al., 2001; Isozaki et al., 2018) を除いてみつかっていない。そのため，冥王代地 球の表層がどのような環境だったのかは，長らく 謎のままだった。しかし，月の地質とジルコン年 代・包有鉱物の研究から新たな地球形成論が導 かれ，その様相が明らかになりつつある（Maruyama and Ebisuzaki, 2017)。

地球は 45.67 億年前に原始惑星系円盤から析 出したダス卜（鉱物の微粒子）が成長し，マグマ オーシャンの時代を経て，45.3 億年前に固化し， 大気・海洋のないドライな惑星として誕生した。 その後, 43.7 億年前頃から氷小惑星の爆撃にさ らされ，42 億年前頃には約 3-4 $\mathrm{km}$ の厚さの海 洋と大気に包まれた惑星となった（Maruyama and Ebisuzaki, 2017)。氷小惑星の重爆撃やプ レート運動がはじまると，それまで無水だった地 表は加水されて表層のコマチアイト火山岩の蛇紋 岩化作用がはじまった。上昇するマントルは，圧 力の低下とともに部分溶融して海洋地殼を形成 し，沈み込むスラブが溶融して大陸地殼の形成が はじまった。

地球の形成プロセスを考えると，マントルを構 成する橄欖岩がマグマから固化する年代は 45.3 億年前と考えられる。ただし，マントル橄欖岩は 対流プロセスを通して，地表からマントル深部ま で何度も対流しマグマを放出してきたはずである。 例えば $10 \mathrm{~cm} /$ year で地表からコアーマントル境界 $2,900 \mathrm{~km}$ 深まで到達する時間は 2,900 万年にす ぎない。橄欖岩の $50 \%$ を超えるコマチアイトマ グマをつくるためには，溶融が起きねばならない。 部分溶融が起きると, マントル橄欖岩の系が部分 的に開き，溶融したコマチアイト質マグマは橄欖 岩から抜けて地表に噴出する。部分溶融によって 放射性年代はリセットされるため，形成される火 山岩の年代は地表に噴出した年代に置き換えられ る。一方，部分溶融作用を被っても溶け残った橄 欖岩は，多くの場合は 45.3 億年前の固化年代の 記録を失わない。地質学者が今日手にする顕生代
の造山帯にみられる橄欖岩は，複数回に及ぶマグ マの流出や蛇紋岩化作用を経験している。ところ が，現在の分析技術では，マントル橄欖岩の系が 開いた年代，部分溶融を免れたマントル橄欖岩の もとの年代を正確に残す同位体年代測定法は確立 されていない。このため，マントル橄欖岩の形成 年代はよくわからないとされている。ただし理論 上は，部分溶融を経験していない橄欖岩の形成年 代は，冥王代の 45.3 億年前にさかのぼるはずで ある。最新の地球形成論によれば，地球の加水作 用は 43.7 億年前にはじまった。この時，地表に 噴出した橄欖岩と水の間の反応によって蛇紋岩化 作用が進み，水素が発生しただろう。43.7-42.0 億年前の約 2 億年の間に進んだ大気海洋成分の付 加 (ABEL 爆撃期; Maruyama and Ebisuzaki, 2017）によって，冥王代大気は $\mathrm{H}_{2} \mathrm{O}-\mathrm{CO}_{2}-\mathrm{N}_{2}$ で 構成される組成からはじまったと考えられる。遊 離酸素はまだなく，地下の局所場で起きる蛇紋岩 化作用が生成する水素によって超還元的な水素環 境場が間欠泉の地下洞窟で生まれただろう。そう した環境こそが地球生命が誕生した場だったと考 えることができる（Ebisuzaki and Maruyama， 2017)。

\section{2）冥王代：自然原子炉間欠泉}

生命誕生場には諸説があるが，本論では Ebisuzaki and Maruyama（2017）によって提案され た冥王代の原初大陸上に普遍的に存在した自然原 子炬間欠泉で生まれたと仮定する。自然原子炉間 欠泉内部は閉鎖空間であるため，蛇紋岩化作用で 発生した水素はより効率的に超還元場を提供した だろう。

冥王代表層環境ではコマチアイト質マグマがい たるところを覆っていた。当時は，マントルポテ ンシャル温度が $1700-1600^{\circ} \mathrm{C}$ に近いような高温 の時代であり，このような場合は，マントル橄欖 岩が 7-8 割溶けてコマチアイト質マグマを生成 する。温度が低下すると，コマチアイト質マグマ は生産されず，太古代以降には玄武岩質マグマに 組成が変化してしまう。つまり，地球内部がまだ 十分に熱い冥王代の時代は，地球表層にコマチア イト質マグマが普遍的にあり，そこでも水素生成 
が進んだが，水素は大気に拡散してしまうため超 還元環境は生まれなかった。冥王代の原初大陸内 部の地下洞窟で生まれた初期生命は，定常的に水 素が発生する超還元場という限られた領域でしか 生息できなかっただろう。

こうして誕生した原始生命は，自然原子炉間欠 泉が駆動するエネルギー物質循環に従って，地下 空間から表層へ強制的に移動させられ，超還元的 な地下空間とは異なる環境へ適応していったと考 えられる。おそらく，太陽エネルギーを利用する 機能や，超酸性の猛毒海洋を生き抜くための細胞 膜, 細胞壁, アクアポリンなどが次々と発明され, さまざまな進化を遂げていったに違いない。しか し，自然原子炉間欠泉内部に残り続けた初期生命 は環境の変化を経験しないはずである。したがっ て，彼らの遺伝子もまた進化しない。

大陸の離合集散を駆動するプレートテクトニク スの運動によって, 冥王代の原初大陸は分裂す る。大陸の分裂時には必ず大陸上にリフトが形成 され，そこが分裂場となって大陸が分断される。 分裂場は正断層の形成とともに沈降し，やがて水 面下に沈み，最終的には中央海嶺となる。つま り，もともと大陸だった場所は，時間とともに中 央海嶺へと変化する。こうした長い時間（数 100 万年〜 1,000 万年）をかけた地質学的なプロセス を通して, 原初大陸表層の間欠泉洞窟や表層の湖 に存在していた OD1 は生息場を拡大し，中央海 嶺熱水系の安定した水素環境場に入り込み, 適応 し生き延びることになる。

その後, 冥王代に存在した広大な原初大陸は, 構造侵食作用によって，徐々に破壊され，沈み込 み帯を通してマントル深部へと運び去られ，40 億年前ごろまでに地球表層から消失する（Maruyama and Ebisuzaki, 2017)。その結果，地球表 層には水素を発生させることができる岩石がほと んどない状態となり，OD1が生き残る場所は, コマチアイト質マグマが供給され，水素発生が可 能な中央海嶺熱水系のみとなった。ただし，中央 海嶺起源のオフィオライトが沈み込み帯でトラッ プされて造山帯にとり込まれ，その岩体に割れ目 に沿って流体が循環し続ければ，OD1 はそこで
生き延びることができる。

\section{3）冥王代から太古代まで：コマチアイト質中 央海嶺熱水系}

太古代（40-25 億年前）には，超苦鉄質火山岩 であるコマチアイトが海洋底において形成され た。南アフリカ・バーバートン緑色岩帯（3.5-3.2 Ga; de Wit et al., 2011)，オーストラリア・ノー スポール地域 (3.5 Ga; Komiya et al., 2002), ジンバブエ・ベリングウェ緑色岩帯 $(2.7 \mathrm{Ga}$; Nisbet et al., 1987）などに太古代のコマチアイ トが現存する。フェノスカンジア・ヴェトレニ地 域（2.4 Ga; Puchtel et al., 1996）には，原生代 の最初期に相当するコマチアイトが残っている。 その後の地質時代では，コロンビア・ゴルゴナ 島の白亜紀コマチアイト $(0.88 \mathrm{Ga}$; Arndt et al., 1997）など，限られた場所でのみコマチアイト 質マグマが噴出している。太古代のコマチアイト 海洋底では，海水とコマチアイトとの間で蛇紋岩 化作用が広く起こっていたと推定される。実際 に，太古代の海洋底コマチアイトが熱水変質作用 により炭酸塩化していたことも明らかになって いる (Kitajima et al., 2001; Terabayashi et al., 2003)。

冥王代に打いても, 中央海嶺の火山岩はコマ チアイトであったと推定されている（Shibuya et $a l ., 2015)$ 。冥王代から太古代前半までは, OD1 は中央海嶺熱水系の軸部から離れた地殼内部でも 熱水循環さえあれば棲息可能であった。軸部から 離れ固化したコマチアイト海洋地殼と, 中央海嶺 軸部のフランクでの正断層に伴う割れ目に沿って 海水が循環し, 内部では水素が生産され，噴出口 まで運ばれたと考えられる。OD1の生息可能環 境が広域的に存在したこの時代は，OD1にとっ て全盛期だったといえる。

\section{4) 太古代から原生代まで：中央海嶺トランス フォーム断層熱水系}

太古代に入ると，マントルの温度が低下し，生 産されるマグマの組成が徐々にコマチアイト質か ら立武岩中心へと変化していく（Komiya et al., 1999, 2002)。中央海嶺マグマの組成変化の結果, 中央海嶺における水素発生量は極端に減り, 太古 

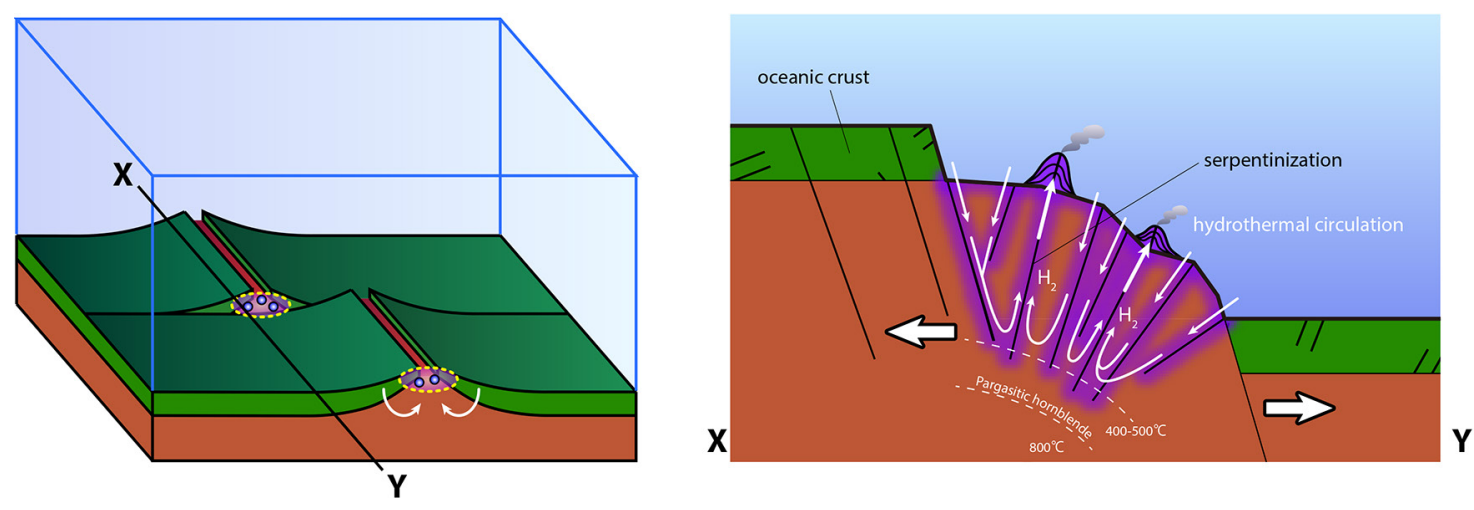

図 5 中央海嶺を切る漏れ型トランスフォーム断層における蛇紋岩化作用の模式図. トランスフォーム断層沿いに海 底面の段差が生じる部分で，正断層に沿って熱水循環が起きる. 橄欖岩が海水と接し，水素ガス発生による超 還元環境を生む。

Fig. 5 Schematic image of mid-oceanic ridge leaky transform fault and serpentinization. The difference in level of the sea-floor along the transform fault generates hydrothermal circulation. Exposed mantle peridotite reacts with seawater and produces hydrogen gas, resulting in an ultra-reducing environment.

代以降になると超還元環境を維持することは難 しくなった。しかし，例外的に水素を発生させ る場が残されていた。それが，トランスフォー 么断層沿いの断層境界である（図 5 ）。このころ の海洋地殼は厚く約 $20 \mathrm{~km}$ 程度の厚さがあった (Komiya et al., 1999)。トランスフォーム断層沿 いに海水が供給されると下位のマントルが加水さ れて膨張し，上昇する。その結果，その断層境界 では橄欖岩が露出し蛇紋岩化が進み, 水素発生場 として機能した。このような地質構造は, 漏れ型 (leaky) トランスフォーム断層と呼ばれる。

冥王代に誕生した OD1 は，コマチアイト質マ グマの供給される中央海嶺熱水系で棲息していた が，太古代になると，OD1の生息場は，もはや 地球表層や中央海嶺の軸部にはなく, 蛇紋岩化が 進行する中央海嶺トランスフォーム断層場に限ら れるようになる。

\section{5）原生代：酸素増加による生息場縮小}

地球表層の酸素濃度は原生代の初期（約 23 億 年前; 大酸化事件 Great Oxidation Event; Holland, 2006） および末期（約 6 億年前；後期原 生代酸素増加事件 Neoproterozoic Oxygenation Event; Canfield et al., 2007）に段階的に増加し た（Lyons et al., 2014）。大陸周辺の浅海域で
は，22 億年前には真核生物が誕生し（澤木ほか， 2019)，6 億年前には多細胞動物が誕生した (Maruyama et al., 2014)。その一方で，深海底 は遊離酸素の増加の影響を受けることなく保た れ，深海においては約 6 億年前にようやく段階 的に溶存酸素濃度が上昇したことが，付加体中の 深海堆積物の酸化還元鋭敏元素の分析から明らか になっている (Kato et al., 2006; Isozaki, 2014; Sato et al., 2015)。このことにより，水素が発生 する場が酸素で囲まれてしまい，超還元場はさら に限られたものとなった。

顕生代に入る前に，大気中の遊離酸素が増大 し，海洋中の酸素濃度も増加した。この後期原生 代酸素増加事件に伴い深海まで酸化的になったこ とが，遠洋深海チャート中の鉄化学種組成（Sato et al., 2015）や，オフィオライトの熱水変質玄武 岩中の鉄化学種組成 (Stolper and Keller, 2018) から明らかになっている。それまで OD1 が生息 していた哚海底まで十分な酸素が供給されるよう になった年代は 564-542 Ma (Sato et al., 2015) と推定される。これによって, OD1の生息場は ますます減少した。しかし，オフィオライトの大 陸プレートへの付加を通して，わずかながら陸上 環境でも OD1 生息場が残された。 
6) 顕生代 : プレート沈み込み帯でのオフィオ ライト付加に伴う陸上蛇紋岩環境の出現

プレート収束境界では，中央海嶺も含めて海洋 プレートがマントル深部へと沈み込んでいく。そ してその過程で, 海洋プレートはオフィオライト （海洋プレート層序を残した岩体）として上盤側 の大陸プレートに橄欖岩体ごとトラップされ付加 体の一部を形成するが，本体の中央海嶺トランス フォーム断層系はマントル深くへと消失する。才 フィオライトの付加には大きく分けて 2 つの夕 イプがある。1つは，オマーン型であり，もう 1 つはタイタオ型である（図 6 )。オマーン型の付 加プロセスでは, 大陸地殼が海洋プレート（橄欖 岩，斑糲岩，シート状ダイク，枕状溶岩）の下に 沈み込み，沈み込んだ海洋スラブが沈み込む大陸 から切れてマントル中へ落ちて行くことにより， スラブ引っ張りの力を失った大陸地殼が上部の海 洋地殼とともに上昇し, その結果, 陸上にオフィ オライト (橄欖岩体) が露出する。一方, タイタ オ型の付加プロセスでは, 中央海嶺の沈み込みに より海洋地殼+マントル（オフイオライト）が大 陸プレートに直接付加する。上盤の大陸地殼が風 化侵食されるに従って, 付加したオフィオライト 岩体が地表に露出する。

オフィオライトが大陸プレートに付加すること によって, OD1 生息場は海洋底から大陸側へと 結果的に移動する。付加したオフィオライトは, 海溝において激しく剪断変形作用を受ける。割れ 目や断層が発達して流体が定常的に流れる場に なる。これにより水素発生場を保たれ，そこで OD1 が生息可能になる。

7）顕生代 : 付加から火山フロントまでの死の 壁

中央海嶺が沈み込み, OD 1 の生息場が大陸側 に移ると，それまで安全だった中央海嶺とは異な り，2つの決定的な「死の壁」に遭遇する。それ は，温度と酸素である。 $\mathrm{OD} 1$ は $100^{\circ} \mathrm{C}$ を超える 高温環境下では生きられない。生息場が大陸側に 移行した後は, 沈み込み带で形成される火山フロ ントの熱から一定以上の距離を保つ必要がある。 また，地表は酸化大気に富むため，地表では生き
延びることができない。また地下環境をみても， 蛇紋岩以外の岩体では高水素濃度を維持すること ができないため，超還元場で棲息してきた OD1 は生き延びることができない（あるいは，やや酸 化的な環境に適応して新しい遺伝子をもつ微生物 になる)。こうした要因を考えると，オフィオラ イトの付加した場が絶妙な深度であることが必要 である。深度が浅すぎると陸上の酸素の攻撃を受 けてしまう。また，十分深い場所に付加すると， 温度が $100^{\circ} \mathrm{C}$ 以上に達してしまい OD 1 は死滅し てしまう。したがって，これらの条件をすべてク リアする環境を綱渡りのようにしてたどってきた と考えられる（図 7 )。付加された海溝陸側斜面 は，断層や割れ目がきわめて良好に発達する場な ので，沈み达みに伴う流体が絶えることなく循環 し，安定した水素発生場を提供しただろう。

\section{8) 現在の地球に残された蛇紋岩熱水系生態系}

現在の OD1 生息場については, III 章で述べ た通りである。代表的な場として, 白馬八方，才 マーン，シダーズ，ハンフォード，ライフル，プ ロニー湾，ロストシティがあげられる（図 3 ）。 ハンフォード，ライフルの両地域は，水素発生場 ではないことが，微生物叢中に占める OD1 の割 合がきわめて少ないことの原因であると推察され る。なかでも, シダーズは比較的高水素濃度が保 たれている (Morrill et al., 2013; Suzuki et al., 2013, 2017）ものの, 岩体として海水から陸地へ と付加された時期が遅いため, 酸素環境を経験し ている可能性がある。オフィオライトの来歴をみ ると, 白馬八方以外の蛇紋岩熱水系は, 顕生代に おける溶存酸素の多い海水環境にさらされた経験 をもつため，そこに棲息する OD1は比較的酸化 的な環境に適応している。これに比べ，白馬八方 温泉の蛇紋岩体（Suda et al., 2014, 2017）は, 深海の酸素濃度が現在と同レベルに上昇する時代 (約 6 億年前) の直前に南中国大陸地殼に付加 し，それ以降は流体循環によって超還元場を保っ てきた岩体である。地下深部 $700 \mathrm{~m}$ の蛇紋岩体 から汲み上げられた温泉水から発見された白馬の OD1は，これまで報告されている OD1のなかで も，もっとも超還元環境での棲息が保たれてき 
(a)
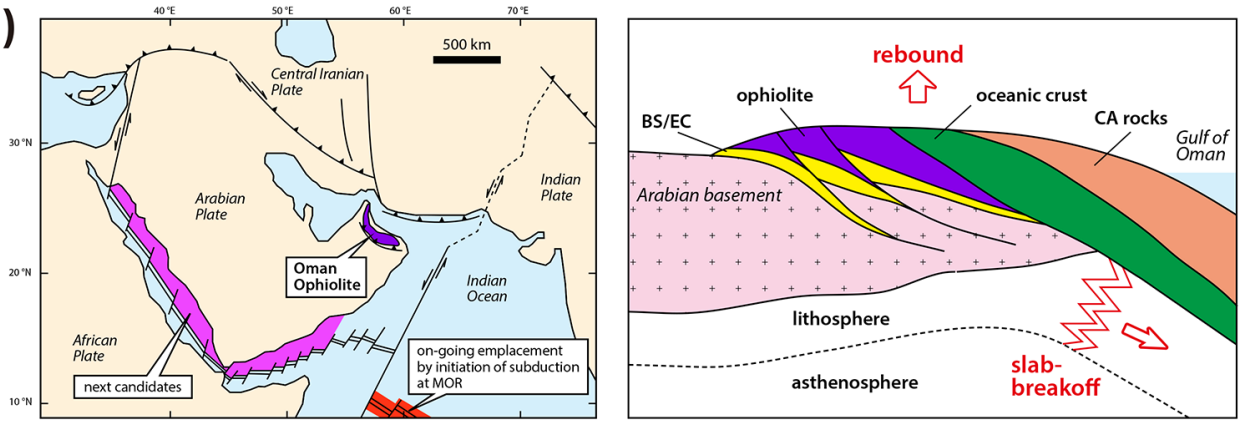

(b)
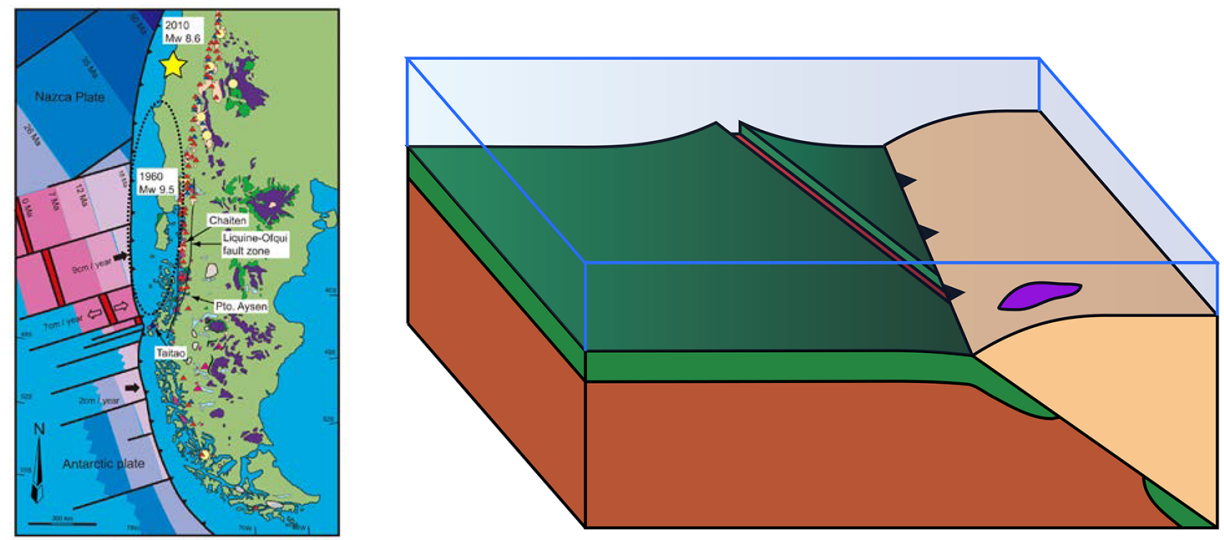

図 6 OD1 を含む橄欖岩体の陸上への付加過程.（a）オマーン型の付加モデル (Searle et al., 2015を改変). (b) タイ タオ型の付加モデル (Anma et al., 2009 を改変).

Fig. 6 Accretion process of peridotite block with OD1 on-land. (a) Oman-type accretion (modified from Searle et al., 2015). (b) Taitao-type accretion (modified from Anma et al., 2009).

\section{Hadean}

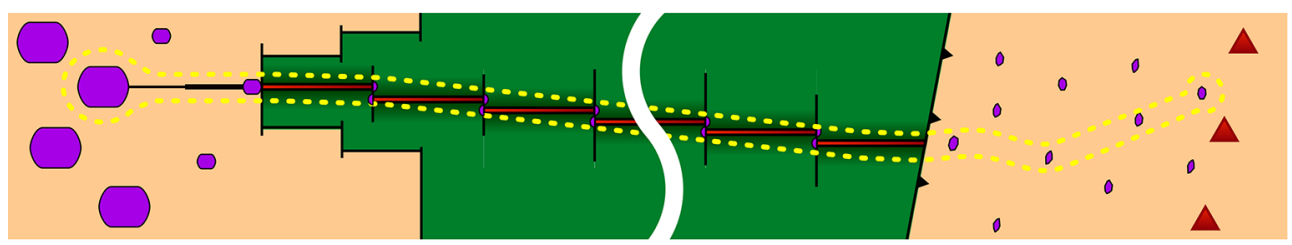

underground

serpentinite-hosted

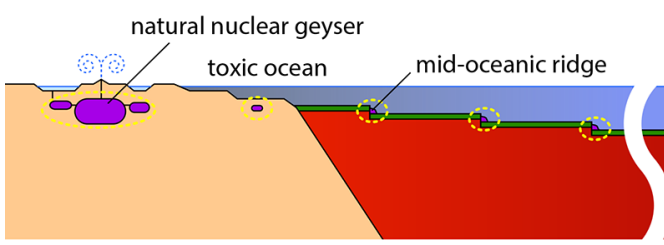

hydrothermal system

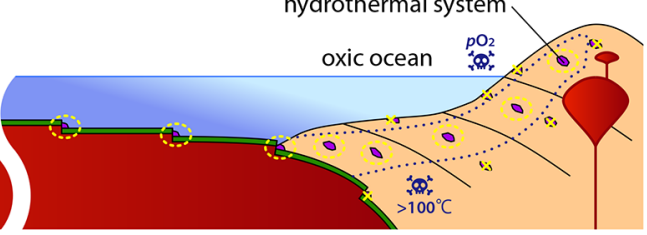

図 7 沈み込み帯における蛇紋岩体の付加の模式図. 点線は生息可能限界=「死の壁」を示す. $100^{\circ} \mathrm{C}$ を超える媣部で はOD1は生存できない.また，表層に接する高酸素環境下でも生存できない.

Fig. 7 Schematic image of accretion of serpentinite blocks in the subduction zone. Dotted lines show the habitable limit of OD1 based on temperature and oxygen concentration. 


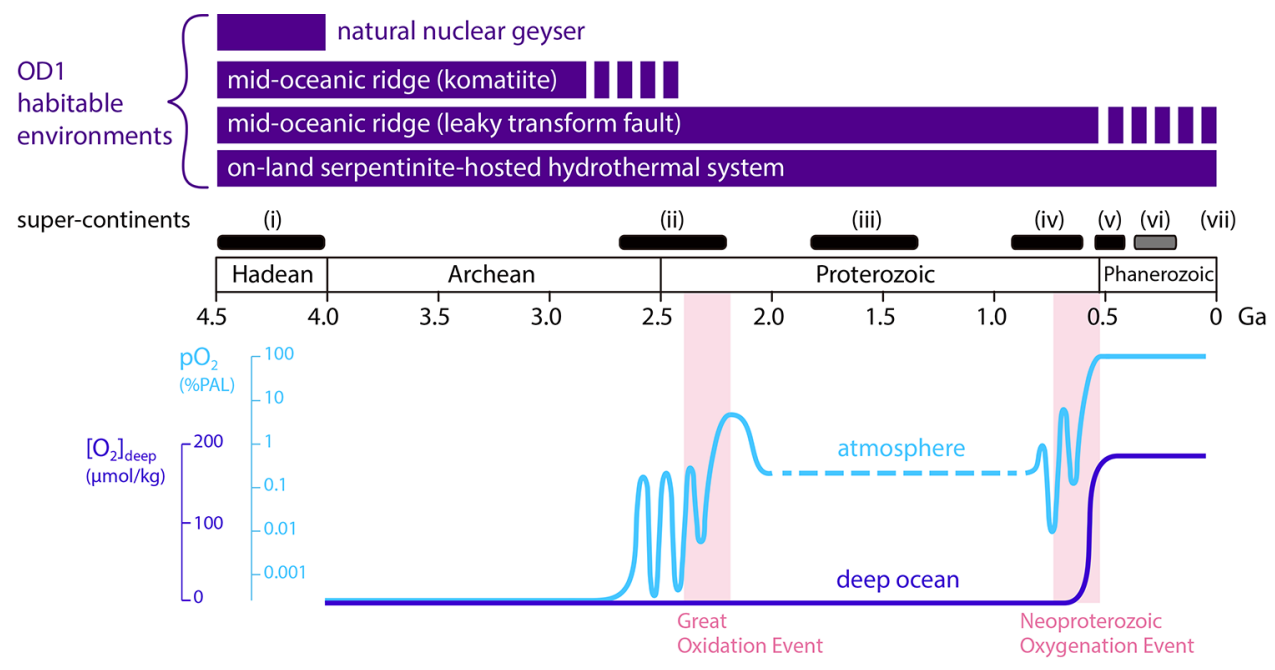

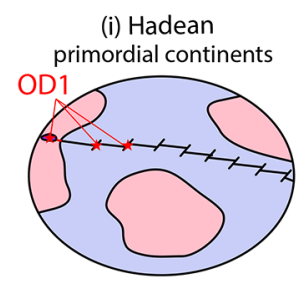

(v) Gondwana

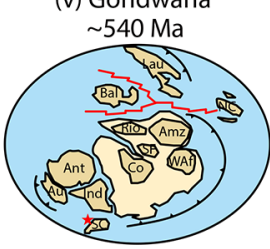

(ii) Kenorland

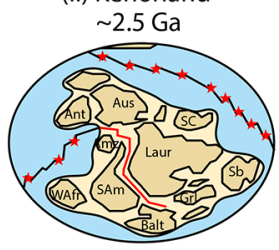

(vi) Pangea

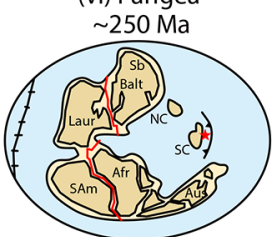

(iii) Nuna (Columbia)

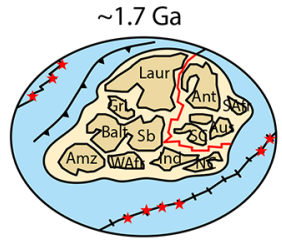

(iv) Rodinia

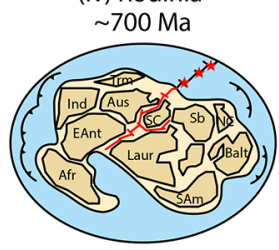

(vii) Present OD1

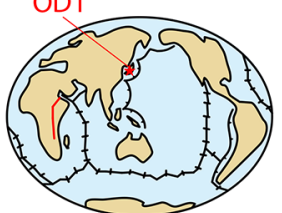

図 8 OD1の生存可能な環境の変遷. 自然原子炬は冥王代の表層に多く存在した。太古代までは，コマチアイト質の 海洋底が存在していた。中央海嶺トランスフォーム断層は，蛇紋岩化作用によって超還元環境を保っていたが， 深海底において酸素が増加した後期原生代酸化事件以降は生存が難しくなったと推定される.現在は, 白馬八方 温泉のような陸上の地下蛇紋岩熱水系が主な生息場である。地球史を通した表層遊離酸素の増加により，生息環 境は減少してきた。冥王代から現在までの OD1の生息場と古地理図。（i）冥王代の原初大陸上で誕生した OD1 が，リフトにより分裂するとともに中央海嶺系へ進出した．超大陸（ii）ケノーランド，(iii）ヌーナ（コロンビア）， （iv）ロディニアの時代は中央海嶺トランスフォーム断層に生息. 海洋が完全に酸化的になる前に付加体に逃げ 込み，その後は（v）ゴンドワナ，（vi）パンゲアの時代を経て，(vii）現在の陸上熱水系のなかで生息してきた 白馬八方の蛇紋岩体は，深海が酸化的になる以前に付加したため，他の蛇紋岩体に比べて超還元場が保たれた.

Fig. 8 Transition of habitats of OD1 through time. In the Hadean, natural nuclear reactors existed extensively on the Earth's surface. In the Archean, komatiite sea-floor was present. Mid-oceanic-ridge transform faults preserved the ultra-reducing environment by serpentinization; however, Neoproterozoic oxygenation of deep-sea water made it difficult for OD1 to live there. At present, OD1 survives only in on-land hydrothermal systems such as Hakuba-Happo hot spring. Habitats of OD1 have decreased as surface oxygen has increased throughout the Earth's history. Paleogeographic map with habitats of OD1 from the Hadean to the present. In the (i) Hadean, OD1 was born in the primordial continent and adapted to the sea-floor mid-oceanic ridge system through rift opening. At the time of supercontinents (ii) Kenorland, (iii) Nuna and (iv) Rodinia, OD1 lived in Mid-oceanic ridge transform faults. After Neoproterozoic oxygenation of the deep seawater from the time of (v) Gondwana, (vi) Pangea, to the (vii) present, OD1 escaped into on-land hydrothermal systems in accretionary complexes. Because the serpentinite block in Hakuba-Happo was accreted to Japan before the oxygenation of deep seawater in the Ediacaran, a super-reducing condition was maintained compared to other sites. 
た，もっとも原始的な OD1 であると期待される。

\section{VII. まとめと今後の展望}

生物の遺伝子解析によって得られる進化系統樹 は，用いる基準によってその特徴が異なってお り，複数の系統樹を組み合わせたからといって遺 伝子進化や遺伝子の新旧を議論することは原理的 に不可能である。ダーウインの自然選択説は，生 物が環境の変化に適応して機能を進化させること が，進化の基本原理であると説明している。裏を 返せば，環境が変わらなければ進化は起きない。 そこでわれわれは，ゲノム進化が起きるための環 境要因と実際の地球史記録を組み合わせ，地球史 に基づくゲノム進化の解読を試みた。最古生物の ゲノムほど冥王代環境の記録を残しているはずで あり，現代に近い時代に誕生した生物ほど，地球 史における最近の表層環境の記録を遺伝子に残し ている。生命は超還元場で誕生し, 酸素濃度に対 する適応進化が不可逆であることを考慮すると， 現在の地球上で超還元場に棲息している微生物で ある OD1は冥王代の「生きた化石」といえる。

超還元場が遍く地球表層に存在した冥王代は, OD1にとって全盛期だったが，地球史を通して 大気中の遊離酸素が増加し, 時代とともに生息場 が縮退するなかで，OD1 はわずかに残された超 還元場で生き延びてきた（図 8 )。地球上の超還 元場は時代とともに減少し, 現在ではごく限られ た場所に存在している。OD1 が冥王代から現在 までどのように超還元場を渡り歩いたのかをまと めると次のようになる。（1）冥王代の自然原子 炉間欠泉からコマチアイト質中央海嶺熱水系の超 還元環境に移動した。（2）太古代後半に， $\mathrm{H}_{2}$ を 生成する超還元場が漏れ型トランスフォーム断層 に限られるようになったため, OD1はそこに生 息場を移動した。（3）顕生代になると，表層の 酸素濃度が増加し, 深海の中央海嶺熱水系にも酸 素がもたらされるようになった。オフィオライト の一部として大陸に付加された蛇紋岩体のなかで, OD1 は生き延びてきた。そのなかでも白馬八方 の蛇紋岩体は, 深海の酸化の直前（約 6 億年前） に大陸地殼へと移動し，超還元環境を保ってきた
ため，白馬の OD1 はもっとも原始的な OD1で あると期待される。

これらの生きている最古の化石生物 OD1（と りわけ白馬の OD1）の研究により，「生命の起 源」研究にきわめて重要な情報が得られると期待 される。まず世界各地に残された OD1の記載分 類を推し進め, OD1 ゲノムのもつ機能の多様性 を明らかにした後，その棲息場の地質学的来歴を 組み合わせることで進化過程の解明が期待され る。また，現時点では培養が困難であるが，棲息 場の物質エネルギー循環および鉱物条件などを再 現することにより，培養は可能になると期待され る。例えば，蛇紋岩に含まれる鉱物（とくに金属 酵素の起源となる二次鉱物 ; 吉屋ほか, 2019）を 入れて増殖したら，OD1 がその鉱物表面での触 媒作用を利用して棲息していることが明らかにな り，さらにゲノム解析によって遺伝子の機能も特 定できるはずである。いざ培養が可能になれば, 「生命の起源」研究のトップダウン・アプローチ の最前線として，最小ゲノムモデル (Xu et al., 2011; Weiss et al., 2016）を用いて，OD1をモ デル微生物とした実験が，次の課題となるだろう。 すでに，蛇紋岩熱水を模した実験系は確立され ており (Shibuya et al., 2015; Ueda et al., 2016, 2017)，ここに微生物実験を組み合わせれば，冥 王代の最古生命棲息場の再現が可能になると考え る。

\section{謝 辞}

本稿は，国立遺伝学研究所の黒川 顕教授をはじめと する新学術領域研究「冥王代生命学の創成」での議論 を通じて得られた見解をまとめた総説であり,ここに 謝意を表する。 2 名の查読者の方には，有益なコメント をいただいた。また，服部玲子氏には，執筆・編集に 際し協力していただいた。深く感謝申し上げる。なお， 本研究は, 科学研究費助成事業・新学術領域研究「冥 王代生命学の創成（課題番号 $26106001 ； 26106002$ )」 の支援を受けて実施した。

\section{文献}

Albertsen, M., Hugenholtz, P., Skarshewski, A., Nielsen, K.L., Tyson, G.W. and Nielsen, P.H. (2013): 
Genome sequences of rare, uncultured bacteria obtained by differential coverage binning of multiple metagenomes. Nature Biotechnology, 31, 533-538.

Alvarez, L.W., Alvarez, W., Asaro, F. and Michel, H.V. (1980): Extraterrestrial cause for CretaceousTertiary extinction. Science, 208, 1095-1108.

Amemiya, C.T., Alföldi, J., Lee, A.P., Fan, S., Philippe, H., MacCallum, I., Braasch, I., Manousaki, T., Schneider, I., Rohner, N., Organ, C., Chalopin, D., Smith, J.J., Robinson, M., Dorrington, R.A., Gerdol, M., Aken, B., Biscotti, M.A., Barucca, M., Baurain, D., Berlin, A.M., Blatch, G.L., Buonocore, F., Burmester, T., Campbell, M.S., Canapa, A., Cannon, J.P., Christoffels, A., De Moro, G., Edkins, A.L., Fan, L., Fausto, A.M., Feiner, N., Forconi, M., Gamieldien, J., Gnerre, S., Gnirke, A., Goldstone, J.V., Haerty, W., Hahn, M.E., Hesse, U., Hoffmann, S., Johnson, J., Karchner, S.I., Kuraku, S., Lara, M., Levin, J.Z., Litman, G.W., Mauceli, E., Miyake, T., Mueller, M.G., Nelson, D.R., Nitsche, A., Olmo, E., Ota, T., Pallavicini, A., Panji, S., Picone, B., Ponting, C.P., Prohaska, S.J., Przybylski, D., Saha, N.R., Ravi, V., Ribeiro, F.J., Sauka-Spengler, T., Scapigliati, G., Searle, S.M.J., Sharpe, T., Simakov, O., Stadler, P.F., Stegeman, J.J., Sumiyama, K., Tabbaa, D., Tafer, H., Turner-Maier, J., van Heusden, P., White, S., Williams, L., Yandell, M., Brinkmann, H., Volff, J.N., Tabin, C.J., Shubin, N., Schartl, M., Jaffe, D.B., Postlethwait, J.H., Venkatesh, B., Di Palma, F., Lander, E.S., Meyer, A. and Lindblad-Toh, K. (2013): The African coelacanth genome provides insights into tetrapod evolution. Nature, 496, 311316.

Anma, R., Armstrong, R., Orihashi, Y., Ike, S.I., Shin, K.C., Kon, Y., Komiya, T., Ota, T., Kagashima, S.I., Shibuya, T., Yamamoto, S., Veloso, E.E., Fanning, M. and Hervé, F. (2009): Are the Taitao granites formed due to subduction of the Chile ridge?. Lithos, 113, 246-258.

Arndt, N.T., Kerr, A.C. and Tarney, J. (1997): Dynamic melting in plume heads: the formation of Gorgona komatiites and basalts. Earth and Planetary Science Letters, 146, 289-301.

Bell, E.A., Boehnke, P.T., Harrison, M. and Mao, W.L. (2015): Potentially biogenic carbon preserved in a 4.1 billion-year-old zircon. Proceedings of the National Academy of Sciences, USA, 112, 14518-14521.

Blattner, F.R., Plunkett, G, Bloch, C.A., Perna, N.T., Burland, V., Riley, M., Collado-Vides, J., Glasner, J.D., Rode, C.K., Mayhew, G.F., Gregor, J., Davis, N.W., Kirkpatrick, H.A., Goeden, M.A., Rose, D.J., Mau, B. and Shao, Y. (1997): The complete genome sequence of Escherichia coli K-12. Science, 277, 1453-1462.

Brazelton, W.J., Ludwig, K.A., Sogin, M.L., Andreishcheva, E.N., Kelley, D.S., Shen, C.C., Edwards, R.L. and Baross, J.A. (2010): Archaea and bacteria with surprising microdiversity show shifts in dominance over 1000-year time scales in hydrothermal chimneys. Proceedings of the National Academy of Sciences, USA, 107, 1612-1617.

Brazelton, W.J., Morrill, P.L., Szponar, N. and Schrenk, M.O. (2013): Bacterial communities associated with subsurface geochemical processes in continental serpentinite springs. Applied and Environmental Microbiology, 79, 3906-3916.

Brazelton, W.J., Thornton, C.N., Hyer, A., Twing, K.I., Longino, A.A., Lang, S.Q., Lilley, M.D., FrühGreen, G.L. and Schrenk, M.O. (2017): Metagenomic identification of active methanogens and methanotrophs in serpentinite springs of the Voltri Massif, Italy. PeerJ, doi:10.7717/peerj.2945.

Brown, C.T. Hug, L.A., Thomas, B.C., Sharon, I., Castelle, C.J, Singh, A., Wilkins, M.J., Wrighton, K.C., Williams, K.H. and Banfield, J.F. (2015): Unusual biology across a group comprising more than $15 \%$ of domain Bacteria. Nature, 523, 208-211.

Canfield, D.E., Poulton, S.W. and Narbonne, G.M. (2007): Late-Neoproterozoic deep-ocean oxygenation and the rise of animal life. Science, 315, 949952.

Cavanaugh, C.M., Gardiner, S.L., Jones, M.L., Jannasch, H.W. and Waterbury, J.B. (1981): Prokaryotic cells in the hydrothermal vent tube worm Riftia pachyptila: Possible chemoautotrophic symbionts. Science, 213, 340-342.

Charlou, J.L., Donval, J.P., Konn, C., Ondreas, H. and Fouquet, Y. (2010): High production and fluxes of $\mathrm{H}_{2}$ and $\mathrm{CH}_{4}$ and evidence of abiotic hydrocarbon synthesis by serpentinization in ultramafic-hosted hydrothermal systems on the Mid-Atlantic Ridge. in Diversity of Hydrothermal Systems on Slow Spreading Ocean Ridges edited by Rona, P., Devey, C.W., Dyment, J. and Murton, B.J., Geophysical Monograph Series, AGU, 188.

Crespo-Medina, M., Twing, K.I., Sánchez-Murillo, R., Brazelton, W.J., McCollom, T.M. and Schrenk, M.O. (2017): Methane dynamics in a tropical serpentinizing environment: The Santa Elena Ophiolite, Costa Rica. Frontiers in Microbiology, doi:10.3389/ fmicb.2017.00916.

Daae, F.L., Økland, I., Dahle, H., Jørgensen, S.L., Thorseth, I.H. and Pedersen, R.B. (2013): Microbial life associated with low-temperature alteration of ultramafic rocks in the Leka ophiolite complex. Geobiology, 11, 318-339.

Danczak, R.E., Yabusaki, S.B., Williams, K.H., Fang, Y., Hobson, C. and Wilkins, M.J. (2016): Snowmelt induced hydrologic perturbations drive dynamic microbiological and geochemical behaviors acrossa shallow riparian aquifer. Frontiers in Earth Science, doi:10.3389/feart.2016.00057.

Darwin, C. (1859): Origin of Species. John Murray, London, 320-324. 
de Wit, M.J., Furnes, H. and Robins, B. (2011): Geology and tectonostratigraphy of the Onverwacht Suite, Barberton Greenstone Belt, South Africa. Precambrian Research, 186, 1-27.

Doolittle, W.F. (1999): Phylogenetic classification and the universal tree. Science, 284, 2124-2128.

Ebisuzaki, T. and Maruyama, S. (2015): United theory of biological evolution: Disaster-forced evolution through Supernova, radioactive ash fall-outs, genome instability, and mass extinctions. Geoscience Frontiers, 6, 103-119.

Ebisuzaki, T. and Maruyama, S. (2017): Nuclear geyser model of the origin of life: Driving force to promote the synthesis of building blocks of life. Geoscience Frontiers, 8, 275-298.

戎崎俊一・西原秀典・黒川 顕 - 森 宙史 ·鎌形洋一 . 玉木秀幸・中井亮佑 - 大島 拓 - 原 正彦 - 鈴木鉄兵 丸山茂徳 (in press): 原子炉間欠泉に駆動された冥王 代原初代謝経路. 地学雑誌. [Ebisuzaki, T., Nishihara, H., Kurokawa, K., Mori, H., Kamagata, Y., Tamaki, H., Nakai, R., Oshima, T., Hara, M., Suzuki, T. and Maruyama, S. (in press): Hadean primordial metabolism pathway driven by a nuclear geyser. Journal of Geography (Chigaku Zasshi). (in Japanese with English abstract) ]

Etiope, G., Tsikouras, B., Kordella, S., Ifandi, E., Christodoulou, D. and Papatheodorou, G. (2013): Methane flux and origin in the Othrys ophiolite hyperalkaline springs, Greece. Chemical Geology, 347, 161-174.

Fox, G., Stackebrandt, E., Hespell, R., Gibson, J., Maniloff, J., Dyer, T., Wolfe, R., Balch, W., Tanner, R., Magrum, L., Zablen, L., Blakemore, R., Gupta, R., Bonen, L., Lewis, B., Stahl, D., Luehrsen, K., Chen, K. and Woese, C. (1980): The phylogeny of prokaryotes. Science, 209, 457-463.

Fraser, C.M., Gocayne, J.D., White, O., Adams, M.D., Clayton, R.A., Fleischmann, R.D., Bult, C.J., Kerlavage, A.R., Sutton, G., Kelley, J.M., Fritchman, R.D., Weidman, J.F., Small, K.V., Sandusky, M., Fuhrmann, J., Nguyen, D., Utterback, T.R., Saudek, D.M., Phillips, C.A., Merrick, J.M., Tomb, J.F., Dougherty, B.A., Bott, K.F., Hu, P.C., Lucier, T.S., Peterson, S.N., Smith, H.O., Hutchison, C.A. and Venter, J.C. (1995): The minimal gene complement of Mycoplasma genitalium. Science, 270, 397-403.

Frouin, E., Bes, M., Ollivier, B., Quéméneur, M., Postec, A., Debroas, D., Armougom, F. and Erauso, G. (2018): Diversity of rare and abundant prokaryotic phylotypes in the Prony hydrothermal field and comparison with other serpentinite-hosted ecosystems. Frontiers in Microbiology, doi:10.3389/fmicb. 2018.00102.

Furnes, H., De Wit, M. and Dilek, Y. (2014): Four billion years of ophiolites reveal secular trends in oceanic crust formation. Geoscience Frontiers, 5, 571-603.
Harris, J.K., Kelley, S.T. and Pace, N.R. (2004): New perspective on uncultured bacterial phylogenetic division OP11. Applied and Environmental Microbiology, 70, 845-849.

Hashimoto, J., Ohta, S., Gamo, T., Chiba, H., Yamaguchi, T., Tsuchida, S., Okudaira, T., Watabe, H., Yamanaka, T. and Kitazawa, M. (2001): First hydrothermal vent communities from the Indian Ocean discovered. Zoological Science, 18, 717-721.

Holland, H.D. (2006): The oxygenation of the atmosphere and oceans. Philosophical Transactions of the Royal Society B, 361, 903-915.

Homma, A. and Tsukahara, H. (2008): Chemical characteristics of hot spring water and geological environment in the northernmost area of the Itoigawa Shizuoka tectonic line. Bulletin of the Earthquake Research Institute, 83, 217-225.

Hug, L.A., Baker, B.J., Anantharaman, K., Brown, C.T., Probst, A.J., Castelle, C.J., Butterfield, C.N., Hernsdorf, A.W., Amano, Y., Ise, K., Suzuki, Y., Dudek, N., Relman, D.A., Finstad, K.M., Amundson, R., Thomas, B.C. and Banfield, J.F. (2016): A new view of the tree of life. Nature Microbiology, $\mathbf{1}$, 16048.

Hugenholtz, P., Pitulle, C., Hershberger, K.L. and Pace, N.R. (1998): Novel division level bacterial diversity in a Yellowstone hot spring. Journal of Bacteriology, 180, 366-376.

猪木幸男・服部 仁・柴田 賢 (1979)：野母半島の変 はんれい岩複合岩体および 4.5 億年基盤岩. 加納 博 教授記念号刊行委員会：日本列島の基盤一加納 博教 授記念論文集，秋田大学，261-280. [Igi, Y., Hattori, H. and Shibata, K. (1979): Metagabbro complex and $400 \mathrm{Ma}$ basement rocks of the Nomo Peninsula: Plutonic rocks and metamorphic rocks. The Basement of the Japanese Islands (Nihon Reto No Kiban Kano Hiroshi Kyoju Kinen Ronbunshu) edited by Editorial Committee of the "Professor Hiroshi Kano Memorial Volume", Akita University, 261-280. (in Japanese)*]

Isozaki, Y. (2009): Integrated "plume winter" scenario for the double-phase extinction during the Paleozoic-Mesozoic transition: The G-LB and P-TB events from a Panthalassan perspective. Journal of Asian Earth Sciences, 36, 459-480.

Isozaki, Y. (2014): Memories of pre-Jurassic lost oceans: How to retrieve them from extant lands. Geoscience Canada, 41, 283-311.

磯崎行雄・丸山茂徳（1991）：日本におけるプレート造 山論の歴史と日本列島の新しい地体構造区分. 地学雑 誌, 100, 697-761. [Isozaki, Y. and Maruyama, S. (1991): Studies on orogeny based on plate tectonics in Japan and new geotectonic subdivision of the Japanese Islands. Journal of Geography (Chigaku Zasshi), 100, 697-761. (in Japanese with English abstract)

磯崎行雄 - 丸山茂徳 - 中間隆晃 · 山本伸次 · 柳井修一 
(2011) : 活動的大陸縁の肥大と縮小の歴史一日本列 島形成史アップデイト一. 地学雑誌， 120，65-99.

[Isozaki, Y., Maruyama, S., Nakama, T., Yamamoto, S. and Yanai, S. (2011): Growth and shrinkage of an active continental margin: Updated geotectonic history of the Japanese Islands. Journal of Geography (Chigaku Zasshi), 120, 65-99. (in Japanese with English abstract)]

Isozaki, Y., Yamamoto, S., Sakata, S., Obayashi, H., Hirata, T., Obori, K.-i., Maebayashi, T., Takeshima, S., Ebisuzaki, T. and Maruyama, S. (2018): Highreliability zircon separation for hunting the oldest material on Earth: An automatic zircon separator with image-processing/microtweezers-manipulating system and double-step dating. Geoscience Frontiers, 9, 1073-1083.

Jørgensen, S.L., Thorseth, I.H., Pedersen, R.B., Baumberger, T. and Schleper, C. (2012): Correlating microbial community profiles with geochemical data in highly stratified sediments from the Arctic MidOcean Ridge. Proceedings of National Academy of Science, USA, 109, E2846-E2855.

Jørgensen, S.L., Thorseth, I.H., Pedersen, R.B., Baumberger, T. and Schleper, C. (2013): Quantitative and phylogenetic study of the deep sea archaeal group in sediments of the arctic mid-ocean spreading ridge. Frontiers in Microbiology, 4, 1-11.

Kataoka, R., Ebisuzaki, T., Miyahara, H. and Maruyama, S. (2014): The Nebula Winter: The united view of the snowball Earth, mass extinctions, and explosive evolution in the late Neoproterozoic and Cambrian periods. Gondwana Research, 25, 11531163.

Kato, Y., Yamaguchi, K.E. and Ohmoto, H. (2006): Rare earth elements in Precambrian banded iron formations: Secular changes of $\mathrm{Ce}$ and $\mathrm{Eu}$ anomalies and evolution of atmospheric oxygen. in Evolution of Early Earth's Atmosphere, Hydrosphere, and Biosphere-Constraints from Ore Deposits edited by Kesler, S.E. and Ohmoto, H., Geological Society of America Memoir, Geological Society of America, 198, 269-289.

Keller, G. (2005): Impacts, volcanism and mass extinctions: Random coincidence or cause and effect?. Australian Journal of Earth Sciences, 52, 725-757.

Kelley, D.S., Karson, J.A., Blackman, D.K., FruhGreen, G.L., Butterfield, D.A., Lilley, M.D., Olson, E.J., Schrenk, M.O., Roe, K.K., Lebon, G.T. and Rivizzigno, P. (2001): An off-axis hydrothermal vent field near the Mid-Atlantic Ridge at $30^{\circ} \mathrm{N}$. Nature, 412, 145-149.

Kelley, D.S., Karson, J.A., Früh-Green, G.L., Yoerger, D.R., Shank, T.M., Butterfield, D.A., Hayes, J.M., Schrenk, M.O., Olson, E.J., Proskurowski, G., Jakuba, M., Bradley, A., Larson, B., Ludwig, K., Glickson, D., Buckman, K., Bradley, A.S., Brazelton, W.J., Roe, K., Elend, M.J., Delacour, A., Bernasconi,
S.M., Lilley, M.D., Baross, J.A., Summons, R.E. and Sylva, S.P. (2005): A serpentinite-hosted ecosystem: The Lost City hydrothermal field. Science, 307, 1428-1434.

Kitajima, K., Maruyama, S., Utsunomiya, S. and Liou, J.G. (2001): Seafloor hydrothermal alteration at an Archaean mid-ocean ridge. Journal of Metamorphic Geology, 19, 583-599.

Komiya, T., Maruyama, S., Masuda, T., Nohda, S., Hayashi, M. and Okamoto, K. (1999): Plate tectonics at 3.8-3.7 Ga: Field evidence from the Isua accretionary complex, southern West Greenland. Journal of Geology, 107, 515-554.

Komiya, T., Maruyama, S., Hirata, T. and Yurimoto, H. (2002): Petrology and geochemistry of MORB and OIB in the mid-Archean North Pole region, Pilbara craton, western Australia: Implications for the composition and temperature of the upper mantle at 3.5 Ga. International Geology Review, 44, 988-1016.

椚座圭太郎・後藤 篤 (2010): 日本列島の形成場一古 太平洋の沈み込み開始を示す飛騨外縁帯の $520 \mathrm{Ma}$ の熱水活動一. 地学雑誌, 119, 279-293. [Kunugiza, K. and Goto, A. (2010): Hydrothermal activity of the Hida-Gaien belt indicating initiation of subduction of proto-Pacific plate in ca. $520 \mathrm{Ma}$. Journal of Geography (Chigaku Zasshi), 119, 279-293. (in Japanese with English abstract) ]

Lang, S.Q., Früh-Green, G.L., Bernasconi, S.M., Lilley, M.D., Proskurowski, G., Méhay, S. and Butterfield, D.A. (2012): Microbial utilization of abiogenic carbon and hydrogen in a serpentinite-hosted system. Geochimica et Cosmochimica Acta, 92, 82-99.

León-Zayas, R., Peoples, L., Biddle, J.F., Podell, S., Novotny, M., Cameron, J., Lasken, R.S. and Bartlett, D.H. (2017): The metabolic potential of the single cell genomes obtained from the Challenger Deep, Mariana Trench within the candidate superphylum Parcubacteria (OD1). Environmental Microbiology, 19, 2769-2784.

Lin, X., Kennedy, D., Fredrickson, J., Bjornstad, B. and Konopka, A. (2012): Vertical stratification of subsurface microbial community composition across geological formations at the Hanford Site. Environmental Microbiology, 14, 414-425.

Luef, B., Frischkorn, K.R., Wrighton, K.C., Holman, H.Y., Birarda, G., Thomas, B.C., Singh, A., Williams, K.H., Siegerist, C.E., Tringe, S.G., Downing, K.H., Comolli, L.R. and Banfield, J.F. (2015): Diverse uncultivated ultra-small bacterial cells in groundwater. Nature Communications, 6, 6372.

Lyons, T.W., Reinhard, C.T. and Planavsky, N.J. (2014): The rise of oxygen in Earth's early ocean and atmosphere. Nature, 506, 307-315.

Martin, W., Baross, J., Kelley, D. and Russell, M.J. (2008): Hydrothermal vents and the origin of life. Nature Reviews Microbiology, 6, 805-814. 
Maruyama, S. and Ebisuzaki, T. (2017): Origin of the Earth: A proposal of new model called ABEL. Geoscience Frontiers, 8, 253-274.

Maruyama, T., Sawaki, Y., Ebisuzaki, T., Ikoma, M., Omori, S. and Komabayashi, T. (2014): Initiation of leaking Earth: An ultimate trigger of the Cambrian explosion. Gondwana Research, 25, 910-944.

Morrill, P.L., Kuenen, J.G., Johnson, O.J., Suzuki, S., Rietze, A., Sessions, A.L., Fogel, M.L. and Nealson, K.H. (2013): Geochemistry and geobiology of a present-day serpentinization site in California: The Cedars. Geochimica Cosmochimica Acta, 109, 222240.

Mulkidjanian, A.Y., Bychkov, A.Y., Dibrova, D.V., Galperin, M.Y., and Koonine, E.V. (2012): Origin of first cells at terrestrial, anoxic geothermal fields. Proceedingof the National Academy of Sciences of the United States of America, 109, E821-830.

Neal, C. and Stanger, G. (1983): Hydrogen generation from mantle source rocks in Oman. Earth and Planetary Science Letters, 66, 315-320.

Nelson, W.C. and Stegen, J. (2015): The reduced genomes of Parcubacteria (OD1) contain signatures of a symbiotic life style. Frontiers of Microbiology, $\mathbf{6}$, 713.

Neubeck, A., Sun, L., Müller, B., Ivarsson, M., Hosgörmez, H., Özcan, D., Broman, C. and Schnürer, A. (2017): Microbial community structure of a serpentine-hosted abiotic gas seepage at the Chimaera ophiolite, Turkey. Applied and Environmental Microbiology, doi:10.1128/AEM.03430-16.

Nimura, T., Ebisuzaki, T. and Maruyama, S. (2016): End-cretaceous cooling and mass extinction driven by a dark cloud encounter. Gondwana Research, 37, 301-307.

Nisbet, E.G., Arndt, N.T., Bickle, M.J., Cameron, W.E., Chauvel, C., Cheadle, M., Hegner, E., Kyser, T.K., Martin, A., Renner, R. and Roedder, E. (1987): Uniquely fresh $2.7 \mathrm{Ga}$ komatiites from the Belingwe greenstone belt, Zimbabwe. Geology, 15, 11471150.

Okada, N., Hamada, M., Ogiwara, I. and Ohshima, K. (1997): SINEs and LINEs share common 3' sequences: A review. Gene, 205, 229-243.

Puchtel, I.S., Hofmann, A.W., Mezger, K., Shchipansky, A.A., Kulikov, V.S. and Kulikova, V.V. (1996): Petrology of a 2.41 Ga remarkably fresh komatiitic basalt lava lake in Lion Hills, central Vetreny Belt, Baltic Shield. Contributions to Mineralogy and Petrology, 124, 273-290.

Quéméneur, M., Bes, M., Postec, A., Mei, N., Hamelin, J., Monnin, C., Chavagnac, V., Payri, C., Pelletier, B., Guentas-Dombrowsky, L., Gérard, M., Pisapia, C., Gérard, E., Ménez, B., Ollivier, B. and Erauso, G. (2014): Spatial distribution of microbial communities in the shallow submarine alkaline hydrothermal field of the Prony Bay, New Caledonia.
Environmental Microbiology Reports, 6, 665-674.

Quéméneur, M., Palvadeau, A., Postec, A., Monnin, C., Chavagnac, V., Ollivier, B. and Erauso, G. (2015): Endolithic microbial communities in carbonate precipitates from serpentinite-hosted hyperalkaline springs of the Voltri Massif (Ligurian Alps, Northern Italy). Environmental Science and Pollution Research, 22, 13613-13624.

Rempfert, K.R., Miller, H.M., Bompard, N., Nothaft, D., Matter, J.M., Kelemen, P., Fierer, N. and Templeton, A.S. (2017): Geological and geochemical controls on subsurface microbial life in the Samail Ophiolite, Oman. Frontiers in Microbiology, doi: 10.3389/fmicb.2017.00056.

Rinke, C., Schwientek, P., Sczyrba, A., Ivanova, N.N., Anderson, I.J., Cheng, J.F., Darling, A., Malfatti, S., Swan, B.K., Gies, E.A., Dodsworth, J.A., Hedlund, B.P., Tsiamis, G., Sievert, S.M., Liu W.T., Eisen, J.A., Hallam, S.J., Kyrpides, N.C., Stepanauskas, R., Rubin, E.M., Hugenholtz, P. and Woyke, T. (2013): Insights into the phylogeny and coding potential of microbial dark matter. Nature, 499, 431437.

Russell, M.J., Hall, A.J. and Martin, W. (2010): Serpentinization as a source of energy at the origin of life. Geobiology, 8, 355-371.

産業技術総合研究所地質調査総合センター編 (2015) : 20 万分の 1 日本シームレス地質図 2015 年 5 月 29 日版. [Geological Survey of Japan, AIST ed. (2015): Seamless Digital Geological Map of Japan $(1: 200,000)$.]

Sato, T., Sawaki, Y., Asanuma, H., Fujisaki, W., Okada, Y., Maruyama, S., Isozaki, Y., Shozugawa, K., Matsuo, M. and Windley, B.F. (2015): Redox condition of the late Neoproterozoic pelagic deep ocean: ${ }^{57} \mathrm{Fe}$ Mössbauer analyses of pelagic mudstones in the Ediacaran accretionary complex, Wales, UK. Tectonophysics, 662, 472-480.

澤木佑介 - 佐藤友彦 - 藤崎 渉 -上田修裕 - 浅沼 尚 丸山茂徳 (2019): 天然原子炬周囲の地質と真核生 物誕生場. 地学雑誌, 128，549-569. [Sawaki, Y., Sato, T., Fujisaki, W., Ueda, H., Asanuma, H. and Maruyama, S. (2019): Geology around natural reactor and birthplace of eukaryotes. Journal of Geography (Chigaku Zasshi), 128, 549-569. (in Japanese with English abstract)]

Searle, M.P., Waters, D.J., Garber, J.M., Rioux, M., Cherry, A.G. and Ambrose, T.K. (2015): Structure and metamorphism beneath the obducting Oman ophiolite: Evidence from the Bani Hamid granulites, northern Oman mountains. Geosphere, 11, 18121836.

Seitz, K.W., Lazar, C.S., Hinrichs, K.U., Teske, A.P. and Baker, B.J. (2016): Genomic reconstruction of a novel, deeply branched sediment archaeal phylum with pathways for acetogenesis and sulfur reduction. ISME Journal, 10, 1696-1705. 
Sepkoski, J.J. (1984): A kinetic-model of Phanerozoic taxonomic diversity. 3. Post-Paleozoic families and mass extinctions. Paleobiology, 10, 246-267.

Shibuya, T., Komiya, T., Nakamura, K., Takai, K. and Maruyama, S. (2010): Highly alkaline, hightemperature hydrothermal fluids in the early Archean ocean. Precambrian Research, 182, 230-238.

Shibuya, T., Yoshizaki, M., Satoh, M., Shimizu, K., Nakamura, K., Omori, S., Suzuki, K., Takai, K., Hideo, T. and Maruyama, S. (2015): Hydrogen-rich hydrothermal environments in the Hadean ocean inferred from serpentinization of komatiites at 300 ${ }^{\circ} \mathrm{C}$ and 500 bar. Progress in Earth and Planetary Science, 2, 1-11.

Spang, A., Saw, J.H., Jørgensen, S.L., ZarembaNiedzwiedzka, K., Martijn, J. and Lind, A.E. (2015): Complex Archaea that bridge the gap between prokaryotes and eukaryotes. Nature, 521, 173-179.

Stolper, D.A. and Keller, B. (2018) : A record of deepocean dissolved $\mathrm{O}_{2}$ from the oxidation state of iron in submarine basalts. Nature, 553, 323-327.

Suda, K., Ueno, U., Yoshizaki, M., Nakamura, H., Kurokawa, K., Nishiyama, E., Yoshino, K., Hongoh, Y., Kawachi, K., Omori, S., Yamada, K., Yoshida, N. and Maruyama, S. (2014): Origin of methane in serpentinite-hosted hydrothermal systems: The $\mathrm{CH}_{4}-\mathrm{H}_{2}-\mathrm{H}_{2} \mathrm{O}$ hydrogen isotope systematics of the Hakuba Happo hot spring. Earth and Planetary Science Letters, 386, 112-125.

Suda, K., Gilbert, A., Yamada, K., Yoshida, N. and Ueno, Y. (2017): Compound- and positionspecific carbon isotopic signatures of abiogenic hydrocarbons from on-land serpentinite-hosted Hakuba Happo hot spring in Japan. Geochemica Cosmochimica Acta, 206, 201-215.

Suzuki, S., Ishii, S., Wu, A., Cheung, A., Tenney, A., Wanger, G., Kuenen, J.G. and Nealson, K.H. (2013): Microbial diversity in The Cedars, an ultrabasic, ultrareducing, and low salinity serpentinizing ecosystem. Proceedings of National Academy of Science, USA, 110, 15336-15341.

Suzuki, S., Ishii, S., Hoshino, T., Rietze, A., Tenney, A., Morrill, P.L., Inagaki, F., Kuenen, J.G. and Nealson, K.H. (2017): Unusual metabolic diversity of hyperalkaliphilic microbial communities associated with subterranean serpentinization at The Cedars. ISME Journal, 11, 2584-2598.

Takai, K., Nakamura, K., Suzuki, K., Inagaki, F., Nealson, K.H. and Kumagai, H. (2006): Ultramaficshydrothermalism- hydrogenesis-hyperslime (ultra $\mathrm{H}^{3}$ ) linkage: A key insight into early microbial ecosystem in the Archean deep-sea hydrothermal systems. Paleontological Research, 10, 269-282.

竹内 誠 - 河合政岐 - 野田 篤 - 杉本憲彦 - 横田秀晴 小嶋 智 - 大野研也 -丹羽正和 - 大場穂高 (2004): 飛騨外縁帯白馬岳地域のペルム系白馬岳層の層序お
よび蛇紋岩との関係. 地質学雑誌, 110, 715-730.

[Takeuchi, M., Kawai, M., Noda, A., Sugimoto, N., Yokota, H., Kojima, S., Ohno, K., Niwa, M. and Ohba, H. (2004): Stratigraphy of the Permian Shiroumadake Formation and its structural relationship with serpentinite in the Mt. Shiroumadake area, Hida Gaien belt, central Japan. Journal of Geological Society of Japan, 110, 715-730. (in Japanese with English abstract) ]

Tarduno, J.A., Cottrell, R.D., Davis, W.J., Nimmo, F. and Bono, R.K. (2015): A Hadean to Paleoarchean geodynamo recorded by single zircon crystals. Science, 349, 521-524.

Tashiro, T., Ishida, A., Hori, M., Igisu, M., Koike, M., Méjean, P., Takahata, N., Sano, Y. and Komiya, T. (2017): Early trace of life from 3.95 Ga sedimentary rocks in Labrador, Canada. Nature, 549, 516.

Terabayashi, M., Masuda, Y. and Ozawa, H. (2003): Archean ocean-floor metamorphism in the North Pole area, Pilbara Craton, Western Australia. Precambrian Research, 123, 167-180.

Tiago, I. and Veríssimo, A. (2013): Microbial and functional diversity of a subterrestrial high $\mathrm{pH}$ groundwater associated to serpentinization. Environmental Microbiology, 15, 1687-1706.

Tsukuda, T. (2000) : Field Study on Predicting Large Inland Earthquakes. University of Tokyo.

Twing, K.I., Brazelton, W.J., Kubo, M.D.Y., Hyer, A.J., Cardace, D., Hoehler, T., McCollom, T.M. and Schrenk, M.O. (2017): Serpentinization-influenced groundwater harbors extremely low diversity microbial communities adapted to high pH. Frontiers in Microbiology, doi:10.3389/fmicb.2017.00308.

Ueda, H., Shibuya, T., Sawaki, Y., Saitoh, M., Takai, K. and Maruyama, S. (2016): Reactions between komatiite and $\mathrm{CO}_{2}$-rich seawater at 250 and $350^{\circ} \mathrm{C}$ at 500 bars: Implications for hydrogen generation in the Hadean seafloor hydrothermal system. Progress in Earth and Planetary Science, doi:10.1186/ s40645-016-0111-8.

Ueda, H., Sawaki, Y. and Maruyama, S. (2017): Reactions between olivine and $\mathrm{CO}_{2}$-rich seawater at $300^{\circ} \mathrm{C}$ : Implications for $\mathrm{H}_{2}$ generation and $\mathrm{CO}_{2}$ sequestration on the early Earth. Geoscience Frontiers, 8, 387-396.

Venter, J.C., Remington, K., Heidelberg, J.F., Halpern, A.L., Rusch, D., Eisen, J.A., Wu, D., Paulsen, I., Nelson, K.E., Nelson, W., Fouts, D.E., Levy, S., Knap, A.H., Lomas, M.W., Nealson, K., White, O., Peterson, J., Hoffman, J., Parsons, R., Baden-Tillson, H., Pfannkoch, C., Rogers, Y.H. and Smith, H.O. (2004): Environmental genome shotgunsequencing of the Sargasso Sea. Science, 304, 66-74.

Weiss, M.C., Sousa, F.L., Mrnjavac, N., Neukirchen, S., Roettger, M., Nelson-Sathi, S. and Martin, W.F. (2016): The physiology and habitat of the last universal common ancestor. Nature Microbiology, 1, 
16116.

Wilde, S.A., Valley, J.W., Peck, W.H. and Graham, C.M. (2001): Evidence from detrital zircons for the existence of continental crust and oceans on the Earth 4.4 Gyr ago. Nature, 409, 175-178.

Woese, C.R. and Fox, G.E. (1977): The concept of cellular evolution. Journal of Molecular Evolution, 10, $1-6$.

Woese, C.R., Kandler, O. and Wheelis, M.L. (1990): Towards a natural system of organisms: Proposal for the domains Archaea, Bacteria, and Eucarya. Proceedings of National Academy of Science, USA, 87, 4576-4579.

Wood, B.L. (1972): Metamorphosed ultramafites and associated formations near Milford Sound, New Zealand. New Zealand Journal of Geology and Geophysics, 15, 88-128.

Woycheese, K.M., Meyer-Dombard, D.R., Cardace, D., Argayosa, A.M. and Arcilla, C.A. (2015): Out of the dark: Transitional subsurface-tosurface microbial diversity in a terrestrial serpentinizing seep (Manleluag, Pangasinan, the Philippines). Frontiers in Microbiology, doi:10.3389/fmicb.2015.00044.

Xu, P., Ge, X., Wang, X, Dou, Y., Xu, J.Z., Patel, R., Stone, V., Trih, M., Kitten, T., Bonchev, D. and
Buck, G.A. (2011): Genome-wide essential gene identification in Streptococcus sanguinis. Scientific Reports, doi:10.1038/srep00125.

Yoon, H.S., Price, D.C., Stepanauskas, R., Rajah, V.D., Sieracki, M.E., Wilson, W.H., Yang, E.C., Duffy, S. and Bhattacharya, D. (2011): Single-cell genomics reveals organismal interactions in uncultivated marine protists. Science, 332, 714-717.

吉屋一美 - 佐藤友彦 - 大森聡一 - 丸山茂徳 (2019) : 原始生命誕生場で起こる岩石一水相互作用と金属夕 ンパク合成のための二次鉱物の役割. 地学雑誌,

128, 625-647. [Yoshiya, K., Sato, T., Omori, S. and Maruyama, S. (2019): Birth place of proto-life: Role of secondary minerals in forming metalloproteins through water-rock interaction. Journal of Geography (Chigaku Zasshi), 128, 625-647. (in Japanese with English abstract)]

Zaremba-Niedzwiedzka, K., Caceres, E.F., Saw, J.H., Bäckström, D., Juzokaite, L., Vancaester, E., Seitz, K.W., Anantharaman, K., Starnawski, P., Kjeldsen, K.U., Stott, M.B., Nunoura, T., Banfield, J.F., Schramm, A., Baker, B.J., Spang, A. and Ettema, T.J.G. (2017): Asgard archaea illuminate the origin of eukaryotic cellular complexity. Nature, 541, 353-358.

* Title etc. translated by T.S. 